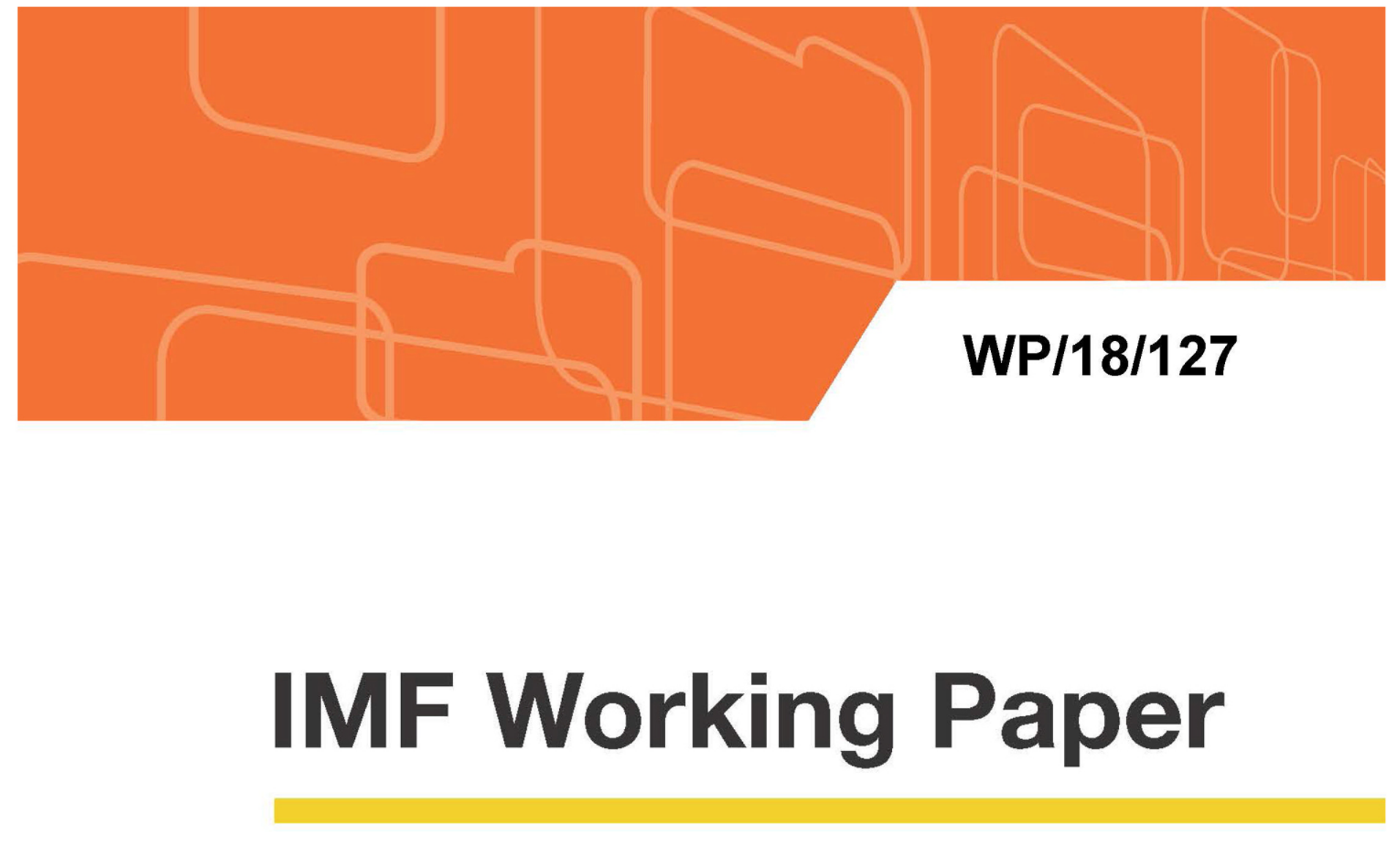

\title{
Inequality in China - Trends, Drivers and Policy Remedies
}

by Sonali Jain-Chandra, Niny Khor, Rui Mano, Johanna Schauer, Philippe Wingender and Juzhong Zhuang

IMF Working Papers describe research in progress by the author(s) and are published to elicit comments and to encourage debate. The views expressed in IMF Working Papers are those of the author(s) and do not necessarily represent the views of the IMF, its Executive Board, or IMF management. 


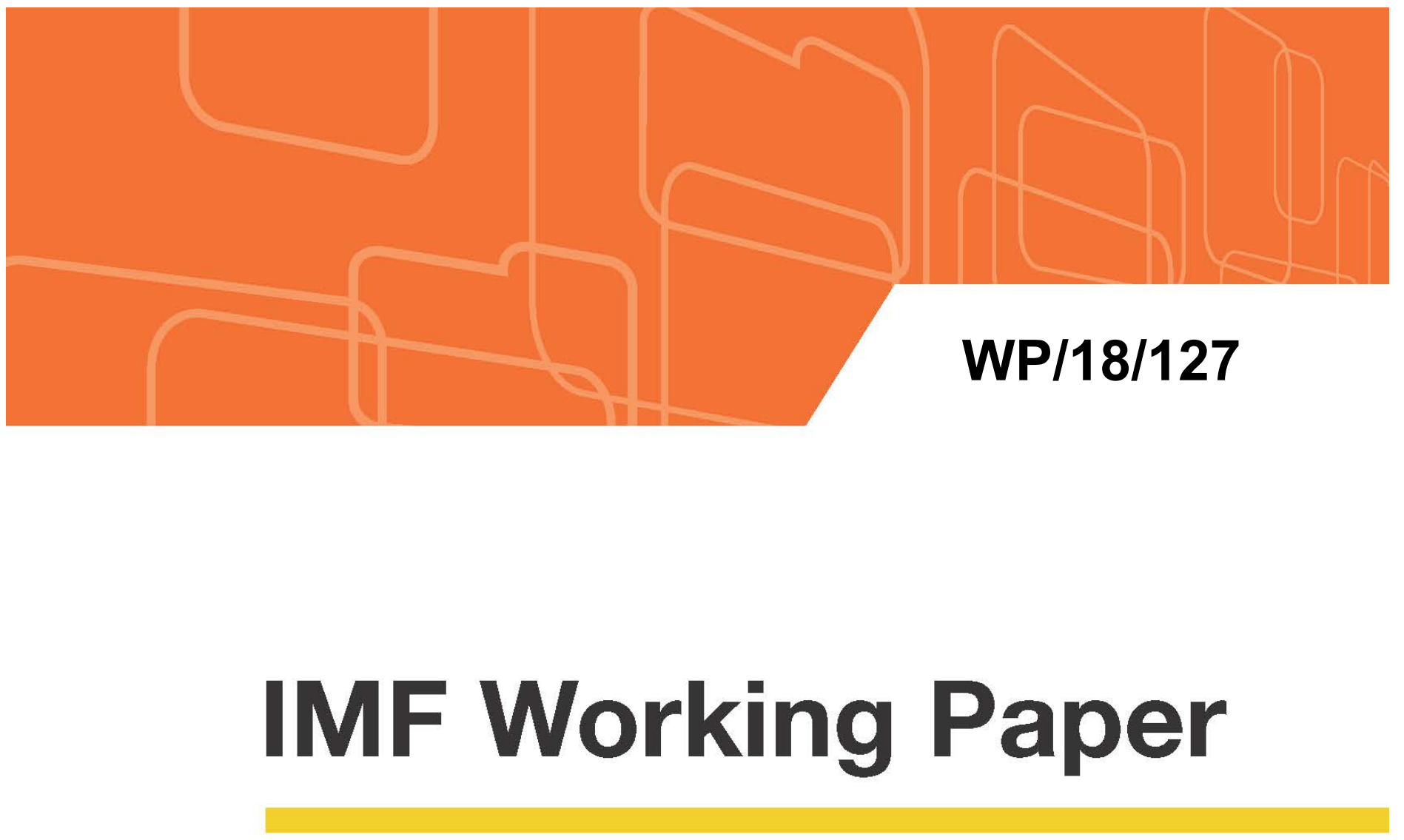

\section{Inequality in China - Trends, Drivers and Policy Remedies}

by Sonali Jain-Chandra, Niny Khor, Rui Mano, Johanna Schauer, Philippe Wingender and Juzhong Zhuang

IMF Working Papers describe research in progress by the author(s) and are published to elicit comments and to encourage debate. The views expressed in IMF Working Papers are those of the author(s) and do not necessarily represent the views of the IMF, its Executive Board, or IMF management.

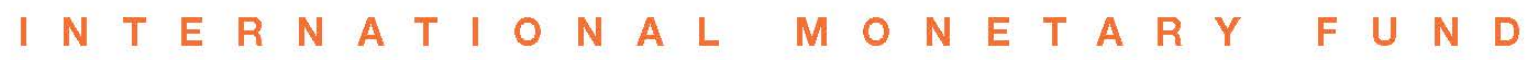




\title{
IMF Working Paper
}

Asia and Pacific Department

\section{Inequality in China - Trends, Drivers and Policy Remedies \\ Prepared by Sonali Jain-Chandra, Niny Khor, Rui Mano, Johanna Schauer, Philippe Wingender and Juzhong Zhuang ${ }^{1}$}

Authorized for distribution by James Daniel

June 2018

IMF Working Papers describe research in progress by the author(s) and are published to elicit comments and to encourage debate. The views expressed in IMF Working Papers are those of the author(s) and do not necessarily represent the views of the IMF, its Executive Board, or IMF management.

\begin{abstract}
China has experienced rapid economic growth over the past two decades and is on the brink of eradicating poverty. However, income inequality increased sharply from the early 1980s and rendered China among the most unequal countries in the world. This trend has started to reverse as China has experienced a modest decline in inequality since 2008. This paper identifies various drivers behind these trends - including structural changes such as urbanization and aging and, more recently, policy initiatives to combat it. It finds that policies will need to play an important role in curbing inequality in the future, as projected structural trends will put further strain on equity considerations. In particular, fiscal policy reforms have the potential to enhance inclusiveness and equity, both on the tax and expenditure side.
\end{abstract}

JEL Classification Numbers: D31, H23, H5

Keywords: income inequality, China, structural change, fiscal policy

\footnotetext{
${ }^{1}$ This paper has greatly benefitted from comments by James Daniel, Huancheng Du, Markus Rodlauer, Alison Stuart, Joao Tovar Jalles, Ryan Wu, Longmei Zhang, and participants of the APD Discussion Forum. All mistakes are our own.
} 
Author's E-Mail Address: sjainchandra@imf.org, nkhor@adb.org, rmano@imf.org, jschauer@imf.org, pwingender@imf.org, jzhuang@adb.org

\section{INTRODUCTION}

Over the past two decades, China has seen a sharp reduction of poverty, but also a substantial increase of inequality. As the result of more than two decades of rapid economic growth in China, millions have been lifted out of poverty, resulting in an impressive decline in the poverty headcount ratio. However, economic growth has not benefited all segments of the population equally or at the same pace, causing income disparities to grow, resulting in a large increase in income inequality (which appears to have peaked around 2008). This is especially of concern as the recent literature has found that elevated levels of inequality are harmful for the pace and sustainability of growth (e.g., Easterly, 2007; Berg and Ostry, 2011; Berg et al., 2012; Ostry et al., 2014; Ostry et al. 2018; Dabla-Norris et al., 2015). High levels of income inequality can lead to suboptimal investment in health and education, which weighs on growth (Galor and Zeira 1993, Banerjee and Newman 1993). Also, widening inequality can weaken the support for growthenhancing reforms and may spur governments to adopt populist policies and weaken reform prospects (Alesina and Rodrik 1994, Alesina and Perotti 1996, Perotti 1996, Posner 1997, Benabou 2002, Rajan 2006).

\section{This paper discusses the evolution and drivers of inequality in China, and possible} policy remedies, with a focus on the role of fiscal policy to combat inequality. It goes beyond standard measures of inequality in outcomes (particularly income inequality) and analyzes inequality in access and opportunities (such as the access to education, social safety net and financial services), which eventually translate into inequitable incomes. In addition, it analyzes the potential effects of key structural changes in China's economy and society such as rebalancing, migration, and aging - on future inequality. Recognizing the widening income disparities, the Chinese government has taken a number of steps and put in place policies to address them. The paper discusses what additional policies can be deployed to improve equity in opportunities and outcomes, with particular focus on the role for fiscal policy.

\section{The main questions the paper seeks to answer are as follows:}

1. What is the current state of income inequality in China? How has it evolved over time and how does China compare to other countries? (Section II)

2. What is the current state of inequality of opportunities and access? (Section III)

3. What are the main drivers that explain trends in inequality? (Section IV)

4. What will be the future impact of structural trends (rebalancing, migration, aging) on inequality? (Section V)

5. What policies has China already implemented to address inequality? (Box) 
6. Which additional policies could reduce inequality? In particular, what could be the role for fiscal policy? (Section VI)

\section{WHAT IS THE CURRENT STATE OF INCOME INEQUALITY? HOW HAS IT EVOLVED OVER TIME?}

\section{China has moved from being a moderately unequal country in 1990 to being one of the most unequal countries. Income inequality in China today, as measured by the Gini coefficient $^{2}$, is among the highest in the world. The Standardized World Income Inequality} Database (SWIID) ${ }^{3}$ estimates the Net Gini ${ }^{4}$ coefficient for China at 50 points as of 2013 , which is above various regional averages and among the highest in Asia (see figure 1). The official estimate by the National Bureau of Statistics (NBS) assessed it slightly lower at 47.3 Gini points. ${ }^{5}$ Furthermore, the Gini coefficient has rapidly increased over the last two decades, by a total of about 15 Gini points since 1990 (see figure 2). A combination of national sources suggests a similar increase of about $12 \frac{1 / 2}{2}$ points. ${ }^{6}$ Given that income

Figure 1: Regional Comparison of Income Inequality Levels $\quad$ Figure 2: Regional Comparison of Income Inequality Trends (Net Gini Index; in Gini points; year of 2015 (or latest available); average across the region) $\quad$ (Net Gini Index; in Gini points; change since 1990; average across the region)

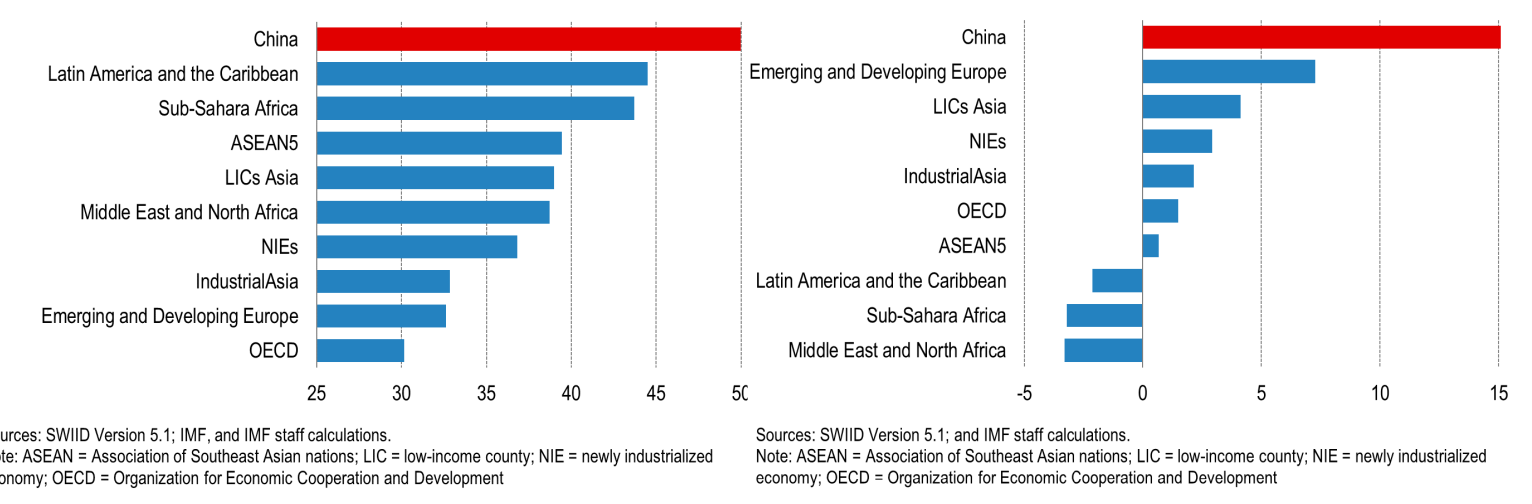

\footnotetext{
${ }^{2}$ The Gini coefficient is an inequality measure ranging from 0 to 100 , where 0 signifies that everyone has the same income (very equal distribution) and 100 implies that the richest person or household has all the income (very unequal distribution).
}

${ }^{3}$ This database aims to combine two major aspects crucial for cross-country analysis - "maximizing the comparability of income inequality data while maintaining the widest possible coverage across countries and over time" (Solt, 2009). This also implies that compromises have been made with the goal of broad crosssectional work in mind (e.g., estimates for many countries that are relatively data-poor depend at least in part on information from other countries). Due to these concerns, we make use of SWIID for cross-country comparison but rely on national estimates for specific country analysis.

${ }^{4}$ The Net Gini coefficient is calculated based on post-tax and -transfer income.

${ }^{5}$ The difference in the Gini coefficient from NBS and the SWIID database is due to the latter adjusting estimates in order to maximize cross-country comparability (for a detailed description see Solt, 2009 and 2016).

${ }^{6}$ Official NBS data only provides Gini coefficients since 2003. Complementing this, we use data from Ravallion and Chen (2007), which uses data directly provided by the CNBS and is the most comprehensive data set providing Gini coefficients annually from 1981 to 2001. This data set provides two coefficients, with one

(continued...) 
inequality, and especially the Gini measure tend to be very persistent over time, this is a considerable rise.

Income inequality increased since the early 1980 s and recently experienced a levelingoff and modest decline. National data sources suggest that the increase in the Gini coefficient dates as far back as the beginning of the 1980s (see figure 3 ). In addition, recent observations point toward a leveling-off or even a slight decline in income inequality since 2008. This has also been acknowledged in the literature (see Zhuang and Shi, 2016 and Kanbur et al., 2017). The most recent official estimate of 2016, at 46.5 points, lies 2.6 points below the highest level observed in 2008. Shifts in the income shares provide a more detailed picture of how the income distribution has changed (see figure 4) ${ }^{7}$. Over the period of increasing inequality from 1980 to 2008 the top 20 percent of adults were gaining income share. Overall, the data suggests that the share of the top 10 percent increased sharply from 26 percent in 1980 to 41.7 percent in 2008 . The modest decline in the Gini coefficient since 2008 was driven by a decline of the share of the top 20 and gains for the middle of the income distribution, rather than an increase in income shares of the bottom deciles. The rise in inequality before 2008 was accompanied by similar trends in the distribution of wealth, with the top 10 percent gaining but the bottom 90 percent losing share (see appendix figure A.1). However, as shown in figure A.1 wealth inequality remained on an upward trend, contrary to the turnaround in income inequality.

Figure 3: China's Gini Coefficient, 1981-2016

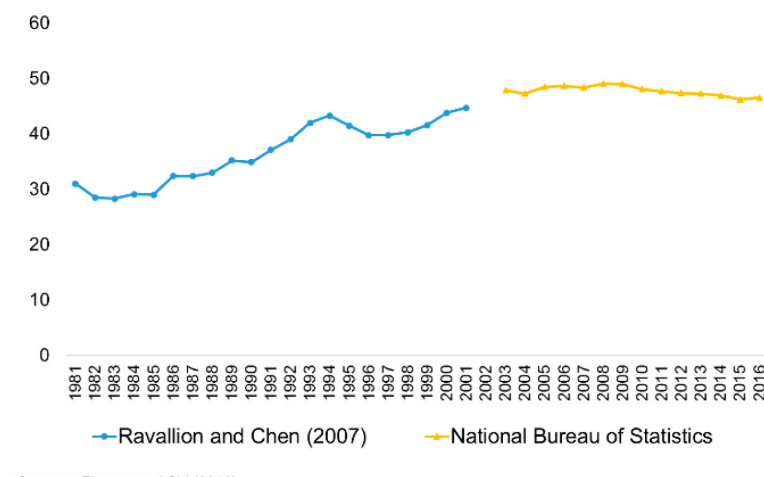

Sources: Zhuang and Shi (2016)

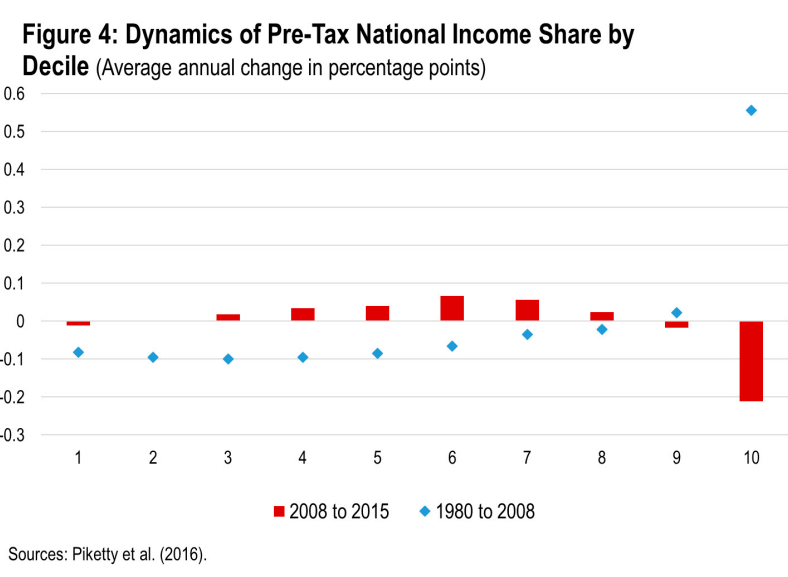

\section{Despite the large increase in income inequality, much of China's population has} experienced rising real incomes. While the largest gains accrued to the upper shares of the income distribution, even for the bottom 10 percent incomes rose by as much as 63 percent between 1980 and 2015 (see figure 5) ${ }^{8}$. This has implied that China reduced the share of

being adjusted for cost of living. Using the Gini coefficient adjusted for cost of living the increase from 1990 to 2013 would be larger at $15 \frac{1}{2}$ percentage points. See appendix A2 for a discussion of the different data sources.

${ }^{7}$ Data from Piketty et al. (2016) is based on the adult individual as observation unit, with income equally split between household members.

${ }^{8}$ See footnote 6 for details on the income concept. 
people living in poverty immensely. Measured by the headcount ratio ${ }^{9}$, the population in poverty decreased by 86 percentage points from 1980 to 2013 (see figure 6), the most rapid reduction in history.

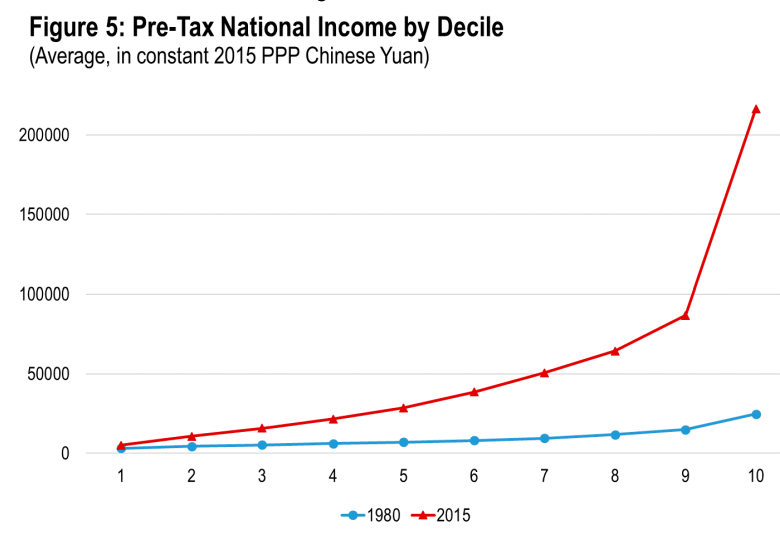

Sources: Piketty et al. (2016).

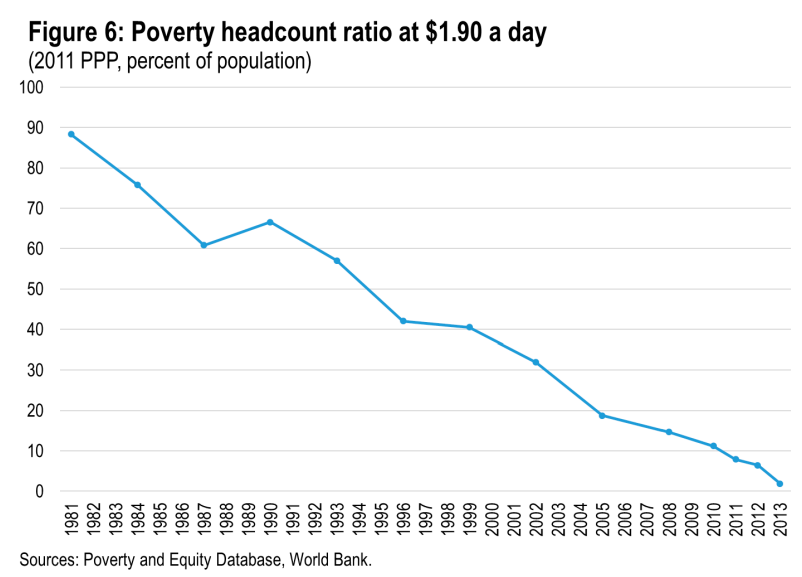

\section{WHAT IS THE CURRENT STATE OF INEQUALITY OF OPPORTUNITY AND ACCESS?}

In addition to inequality of outcomes such as income, it is crucial to determine the extent of inequality of opportunities, such as access to education, health and financial services. These are fundamentally of even greater concern as they sow the seeds for wider income inequality in the future and delink economic outcomes from an individual's efforts.

\section{Despite significant progress, China also faces considerable inequality in opportunities,} such as completion of higher tertiary education and access to certain financial services. While China managed to drastically increase secondary and tertiary enrolment ratios since the 1980 s, in 2010 , tertiary education was more unequally distributed than in other emerging and advanced economies on various dimensions, including based on regional, rural-urban and wealth differences (see figure 7). Access to financial services has also increased significantly in recent years in particular with regards to access and use of internet- and

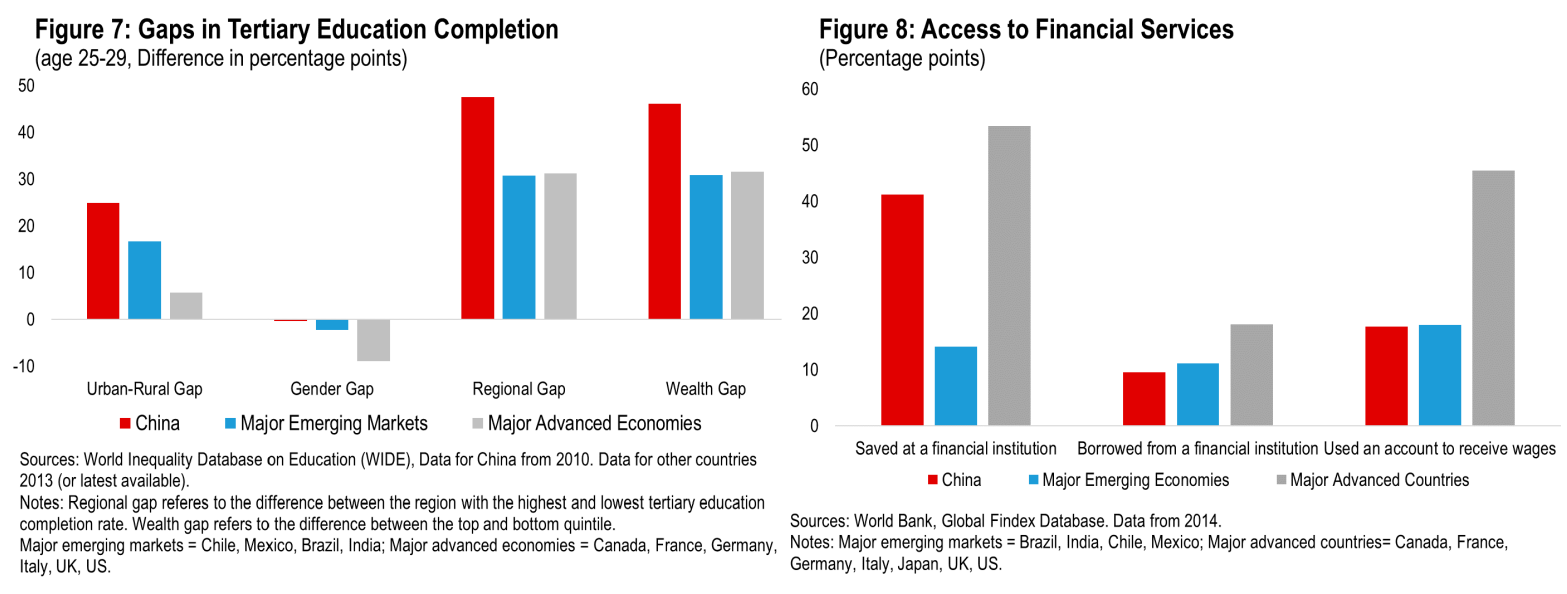

\footnotetext{
${ }^{9}$ The headcount ratio is defined as the percentage of the population living in households with consumption per
} person below the chosen poverty line (here $\$ 1.90$ a day at $2011 \mathrm{PPP}$ ). 
mobile-based payments (World Bank and the People's Bank of China, 2018). However, China still lags major advanced economies along important financial inclusion dimensions including in terms of borrowing and other transaction services (see figure 8). While 41 percent of China's population saved at a financial institution, only 10 percent borrowed from a financial institution and 17 percent used an account to receive wages. These gaps can partly be explained by rural-urban, educational, and income differences (see appendix figure A.2).

China has achieved high levels of legal health and pension coverage, but there is room to increase unemployment insurance coverage and the safety net for the elderly. Equal access to basic social services hinges on two main factors - coverage and the level of transfers received. Almost all of China's population has legal health care coverage, which is largely on account of the success of the New Rural Cooperative Medicare. Moreover, 74 percent of the population above statutory pensionable age is receiving an old age pension (see figure 9). This is ahead of other major emerging markets and close to major advanced economies. However, China is lagging advanced countries when it comes to coverage of unemployment benefits. In addition, out-of-pocket expenditure as a percentage of total health expenditure is still much higher than the average of major advanced countries (see figure 10). The gross pension replacement rate for urban workers is generous. Yet, the benefits an individual receives in case they did not contribute towards their pension is comparatively very low, implying a weak safety net for the elderly.

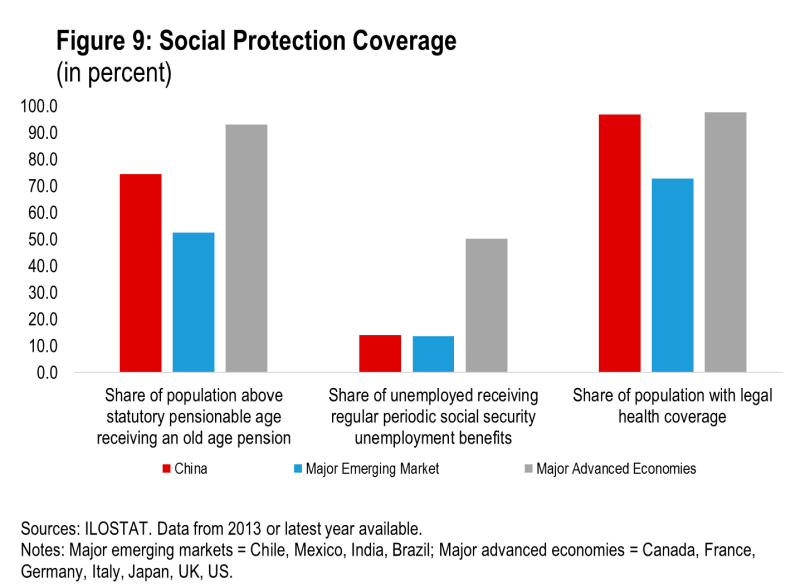

Netes: Major emerging markets

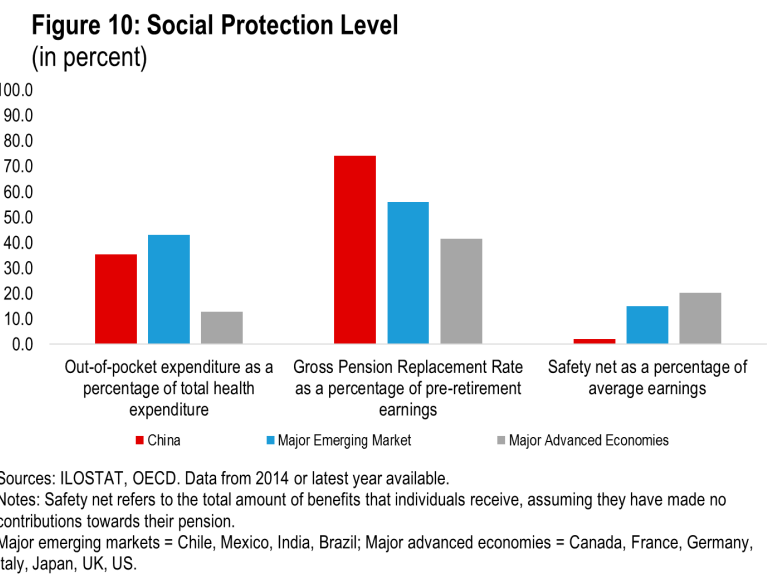

Figure 10: Social Protection Level (in percent)

50.0

0.0

Out-of-pocket expenditure as a Gross Pension Replacement Rate Safety net as a percentage of

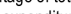
contributions towards their pension. Italy, Japan, UK, US.

\section{WHAT ARE THE MAIN DRIVERS THAT EXPLAIN TRENDS IN INEQUALITY?}

This section discusses key drivers of the two main trends observed in China's income inequality - the increase from 1980 to 2008 and the recent leveling-off and modest decline. Calculating the Theil Index on three waves of the China Household Income Project (CHIP) household surveys, the contribution of education, geographical gaps (urban/rural and provincial) and sector of employment are examined. We find that while all these factors have contributed to the recent leveling-off in inequality, only education and the rural-urban gap appear to be drivers of the previous increase.

\section{Methodology}


The Theil index is applied to measure income inequality. Like the Gini coefficient, the Theil index can be used to measure inequality. It is zero if everyone receives equal income, and increases with a more unequal distribtion. The Theil index is calculated using the formula

$$
T=\frac{1}{N} \sum_{i=1}^{n} \frac{y_{i}}{\bar{y}} \ln \left(\frac{y_{i}}{\bar{y}}\right),
$$

where $y_{i}$ is per-capita income of household $i$ and $\bar{y}$ is the sample mean of per-capita income. $N$ is the number of households in the sample.

Income inequality is decomposed by different subgroups. Unlike the Gini coefficient, the Theil index has the desirable property of decomposability. This allows us to divide total inequality into the part due to inequality within certain population subgroups (e.g., urban population) and the part due to differences between the subgroups (e.g. the rural-urban income gap). Assuming that the total sample households consist of $h$ subgroups and the Theil index of each subgroup is $T_{g}$, the index of the entire sample can be computed as

$$
T=\sum_{g=1}^{h} s_{g} T_{g}+\sum_{g=1}^{h} s_{g} \ln \left(\frac{s_{g}}{p_{g}}\right) .
$$

The first term in the equation above is the average of the Theil indexes of all subgroups weighted by their respective income shares $s_{g}$, and represents the component of overall inequality that is due to inequality within each subgroup, called within-inequality. The second summation is the Theil's T index calculated on the mean income of each subgroup, and represents the component of overall inequality that is due to between-group inequality. Here, $p_{g}$ is subgroup $g$ 's share in the total number of sample households.

We consider four types of decompositions over three different waves. We split the samples into different subgroups according to province, rural-urban location, educational attainment and sector of employment of the household head. Education levels are classified into six subgroups, while provinces have up to 19 subgroups. The sectors of employment included in the analysis are without work, agriculture, secondary sector, and services. The waves are chosen to capture the two main trends on China's inequality development (i.e., the increase and recent levelling-off) and include the years 1995, 2007 and 2013. ${ }^{10}$

\section{Results}

Differences in education and the skill premium are significant drivers of the increase and the subsequent modest decline in income inequality. Based on the decomposition, the share of total income inequality accounted for by differences in educational attainment of the household head (between-group inequality) increased from 20 percent in 1995 to around 32 percent in 2007, subsequently declining to 26 percent in 2013 (figure 11). ${ }^{11}$ China started its

\footnotetext{
${ }^{10}$ See appendix for a detailed description of the dataset.

11 This corresponds to an increase in the Theil index for between-group inequality from 0.07 in 1995 to 0.13 in 2007 and a subsequent fall to 0.09 in 2013.
} 
transition period with impressively high primary and middle school enrollment rates, while lagging in tertiary enrollment (Heckman and Yi, 2012). With rapid technological transformation and fast capital accumulation, the demand for high-skilled labor grew quickly and with it returns to education and wage inequality (Dollar, 2007; Zhang et al., 2005; Liu, 2009). More recent empirical evidence suggests an easing or even decrease in the skill premium between 2008 and 2014 (see figure 12). This could be driven by a glut in graduates as it has been reported that many university graduates find it difficult to find suitable jobs, leading to high unemployment among these graduates and a decline in the skill premium (Chan 2015; Knight et al., 2016). Another cause could be recent hikes in minimum wages (see box).
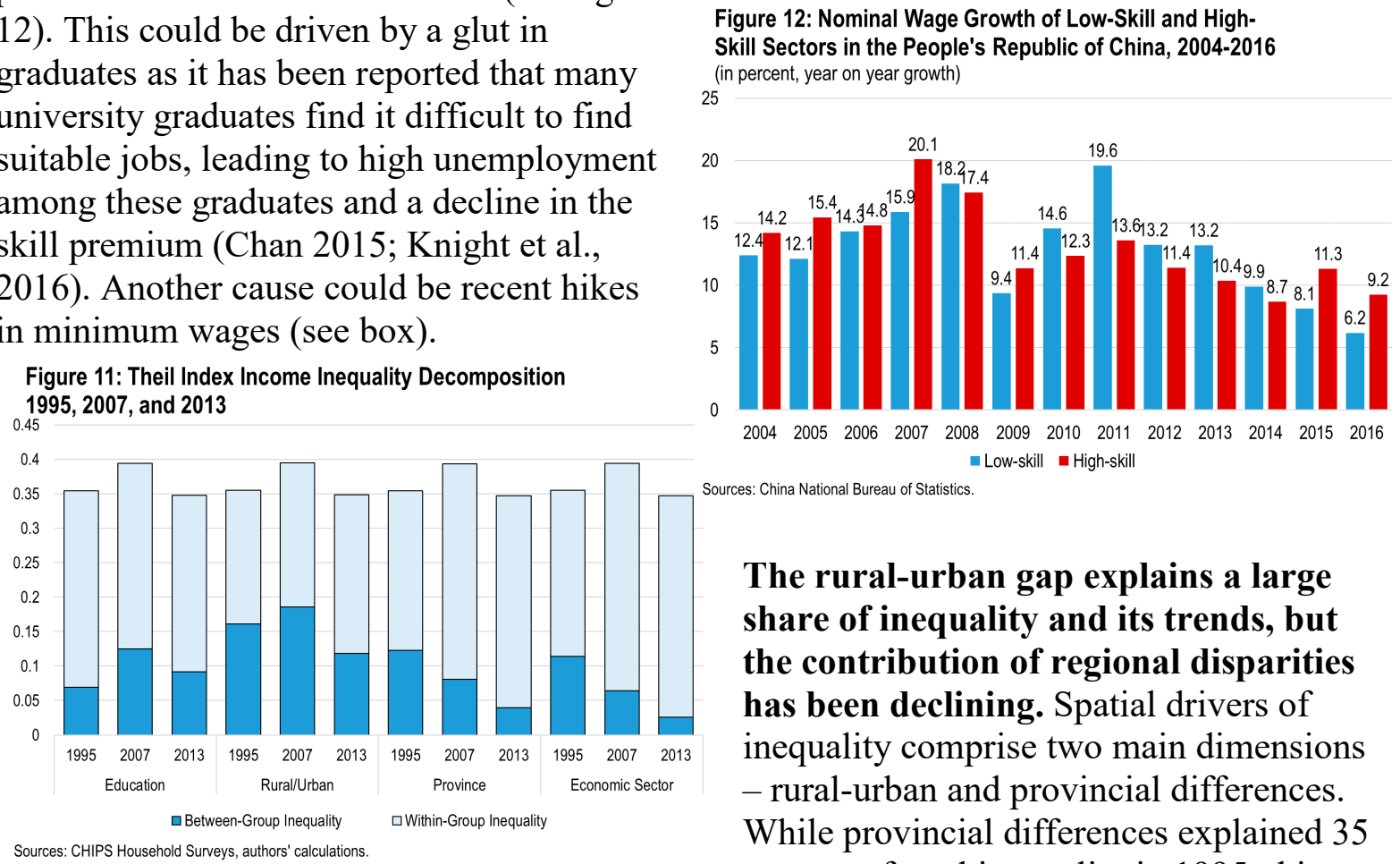

The rural-urban gap explains a large share of inequality and its trends, but the contribution of regional disparities has been declining. Spatial drivers of inequality comprise two main dimensions - rural-urban and provincial differences. While provincial differences explained 35 percent of total inequality in 1995, this

share has subsequently declined to only 11 percent in 2013 . The share of total income inequality accounted for by the rural-urban gap stood at 44 percent in 1995 and increased further in 2007 , to then decline to 34 percent in 2013. Indeed, differences between rural and urban areas have been found to be a key driver of rising income inequality in China and the most important determinant of the level of inequality (Li et al., 2014; Lin et al., 2010). Contributing to this inequality was low educational attainment and low returns to education in rural areas, with the hukou system constraining rural-urban migration and thereby exacerbating these effects (Liu, 2005; Dollar, 2007). However, the data

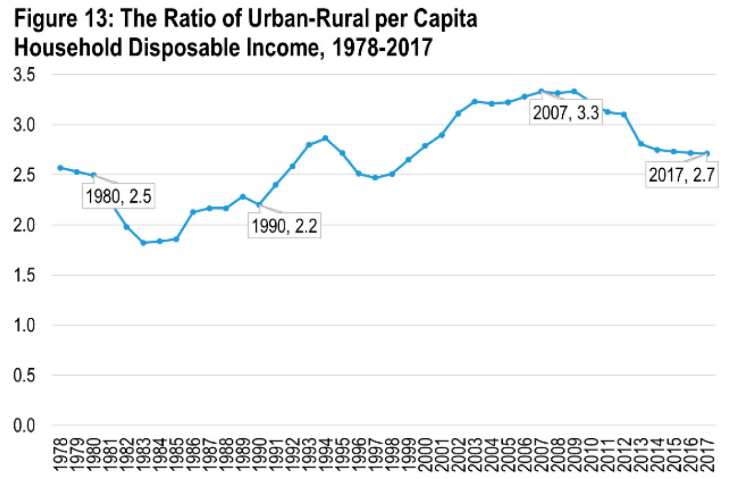

Sources: China National Bureau of Statistics. analysis suggests that the urban-rural income gap in China has started to decline since 2007, which is also supported by the ratio of urban-rural income (see figure 13). Factors that have been suggested as an explanation include rapid urbanization, causing a decline in rural surplus labor, (Zhuang and Shi, 2016) and government policies (see box). 


\section{Differences in income based on the sector of employment have declined sharply,} contributing to the recent decline in inequality. The share of income inequality accounted for by differences in the sector of employment was high at 32 percent in 1995. However, it has since declined to 8 percent in 2013. Within the sectors inequality rose most for those without work from 7 percent to 30 percent, suggesting an uneven provision of social protection. Inequality also rose within services from 8 to 13 percent.

Box. What policies has China implemented to address inequality?

Concerns over the income distribution in China have been increasing in recent years, although generally targeting extreme absolute poverty rather than a broader concept of inequality. In the Twelfth Five Year Plan, the government reiterated its commitment to "speeding up the formation of a reasonable pattern of income distribution ...., and reversing the widening income gap as soon as possible" (State Council of the PRC 2011). This concern over inequality persisted and was articulated in the Thirteenth five Year Plan (2016-2020), which reiterated the goal to eradicate rural poverty by 2020. In the first session of the $13^{\text {th }}$ National People's Congress of March 2018, premier Li announced the target of lifting 10 million people out of poverty in 2018 out of an estimated close to 27 million remaining at the end of 2017. Policy reforms have been initiated in a number of areas:

Personal Income Tax Reform. In response to concerns over rising inequality, the government raised the minimum threshold for personal income tax multiple times from 800 yuan per month before 2005 to 3,500 yuan per month in 2011 . The threshold remained in place as of 2017 , and is now equivalent to 78 percent of GDP per capita. However, it is estimated that only a small share of income earners actually pay the tax and various studies have found the redistributive effect of the personal income tax to be very limited (Zhuang and Shi, 2016; Li et al., 2012, 2014; Lam and Wingender, 2015).

Labor market policies. After a hiatus in 2009, significant annual hikes in minimum wages resumed in 2010. As a result, by 2015 the average ratio of minimum wage to average wage had increased to 31.2 percent in the non-private sector and 51.2 percent in the private sector. While the role of the minimum wage regulation in reducing wage inequality was believed to be limited, the recent hikes and better enforcement have led to a change in this view (Lin and Yun, 2016).

The Dibao system. By 2016 the minimum income guarantee system covered 45.8 million rural residents (7.8 percent out of the total rural population). Another 4.97 million rural residents received relief assistance for extreme poverty. In contrast, 14.9 million urban residents, approximately 1.9 percent of the urban population, participated in the program. Empirical studies find that while the Dibao program did not have a significant impact on reducing income inequality, it has been effective in alleviating poverty ( $\mathrm{Li}$ and Yang 2009).

Pro-farmer policies. Since 2000, China implemented a series of pro-farmer policies as part of its balanced development strategy and measures to reduce urban-rural income gaps. These policies included various direct subsidies, the abolishment of the agricultural tax and improvement of public services and social protection. These pro-farmer policies have been found to play an important role in increasing farmers' incomes and reducing the income gaps between urban and rural areas (Hoken et al., 2016; Li et al., 2013).

Social security. Largely on account of the New Rural Cooperative Medicare, China accomplished rapid expansion in medical care coverage, achieving near-universal coverage for rural residents. In addition, a total of 378 million people participated in the urban basic pension program for workers by the end of 2016. Another 508 million participated in the basic pension insurance program for urban 
and rural residents. However, because of the differences in the scope and level of coverage among different groups, it is not clear to what extent the advances in the social security system have narrowed inequality nationwide (Zhuang et al., 2012; Li and Luo, 2010; Cai and Yue, 2016; Hoken et al., 2016).

Regional development strategy and fiscal transfer policies. During much of the early reform period, economic growth was higher in the coastal region than in the western region, and this led to widening regional disparity. In response, the government adopted the Western Development Strategy in 2000, which included inter alia improvement of infrastructure, preferential policies for foreign investment and significant increases in fiscal transfers to western regions. Moreover, the share of general purpose grants in the transfer system has grown since the early 2000s and there is evidence that they have reduced fiscal disparities and other indicators of development across regions (Wang and Herd, 2013; Hofman and Guerra, 2007). As a result, the income gap between coastal and western regions has decreased since the mid-2000s (Li et al., 2014). In 2014, China unveiled its urbanization plan, which is also seen as a policy to moderate inequality. It aims to move approximately 100 million additional rural residents into urban areas by 2020, thereby reducing the urban-rural income gap. In addition, the Human Rights Action Plan 2016 called for the implementation of the State Council's reform program of the household registration system, and establishing a unified urban-rural household registration system.

Poverty alleviation policies. China started to implement antipoverty policies in the mid-1980s. On account of both the poverty alleviation policies and high economic growth, China's rural poverty rate has declined considerably (Li et al., 2014). More recently, the 13th Five-Year Plan for the Development of Education (2016-2020) called for making three-year preschool and senior high school education universal, with special support to central and western regions as well as rural or povertystricken areas. The plan also stipulated equal access to compulsory education at local schools for the children of migrant workers, and improving the education system for left-behind children.

Financial inclusion. Over the last 15 years, the Chinese government has actively implemented a wide range of policies to bolster financial inclusion. These included guidelines to promote the expansion of payments systems in remote and rural areas, regulations for new types of rural financial service providers and sub-branches and promotion of agent-based service points for cash withdrawal, among others. In addition, in 2014 the China Banking Regulatory Commission set the objective to reach coverage of basic financial services in all villages in three to five years. These comprehensive efforts have shown significant results with ATMs and point-of-sales more than doubling from 2011 to 2016 and agent-based service points for cash withdrawal covering almost all rural towns in China. Yet, some gaps remain (see section III), which the government is actively addressing through its Plan for Advancing the Development of Financial Inclusion issued in 2015 (World Bank and the People's Bank of China, 2018).

\section{LOOKING AHEAD: WHAT WILL BE THE IMPACT OF STRUCTURAL TRENDS AND POLICIES ON INEQUALITY IN THE FUTURE?}

This section uses a cross-country panel to (i) compare the historic trend in inequality in China to other countries, to (ii) quantify the impact of policies and structural factors and to (iii) predict levels of inequality in the future based on projections of structural trends and active policy adjustments. We find that structural factors have played a major role in China's rising inequality, and will keep inequality elevated in the foreseeable future, absent policy changes. Fiscal policy can be a powerful tool and a more pro-active scenario has the potential to quell the rise in inequality. 


\section{Methodology $y^{12}$}

Using a fixed-effects panel regression approach, we estimate the importance of different drivers of China's inequality. We use a panel regression to explain changes in the net Gini index across a panel of 28 countries and spanning roughly 1980-2010. ${ }^{13,14}$ The cross-country regression takes the following form:

$$
\text { Net } \text { Gini }_{c, t}=\alpha+\beta \times S_{c, t}^{\prime}+\gamma \times P_{c, t}^{\prime}+\mu_{c}+\varepsilon_{c, t},
$$

where $S$ is a vector containing the structural variables, $P$ includes policy variables, and $\mu$ the country-fixed effects. A fixed effects specification is chosen to control for omitted invariant factors that may explain cross-country differences in the average level of inequality, such as idiosyncratic historical factors and quality of institutions.

The structural variables include urbanization, aging, sectoral change, and educational levels. In particular,

- Urbanization is measured by the share of the population living in urban areas. Urbanization is often believed to be a main driver of inequality (Behrens and RobertNicoud 2014) and the relationship between inequality and urbanization follows an inverted U-shape (Rauch 1993). This relationship is also often linked to the Kuznets effect (see footnote 14 below).

- Aging is estimated through the Higgins (1998) variables. These variables are constructed from approximating the population age distribution through a third order polynomial. Inequality has long been thought to depend on the age structure of a country's population. Deaton and Paxson $(1994,1997)$ show that within-cohort income inequality rises with age as a consequence of behavior consistent with the permanent income hypothesis in the presence of limited risk sharing.

- Sectoral change is measured by the share of employment in the services and industry sector. Sectoral change is intimately related to urbanization and development and thus is often associated with the Kuznets effect.

- Educational levels are estimated through the share of the population with higher education. While many empirical studies have illustrated a negative impact of education on inequality (De Gregorio and Lee, 2002 and references therein), the theoretical relationship remains ambiguous because of possibly conflicting effects (Knight and Sabot, 1983). The "composition" effect predicts a v-shape relationship with an increase in educational attainment causing initially higher inequality which then reverses at a certain point as the group of high skilled expands. The "wage compression" effect lowers the skill premium and income inequality as the relative supply of educated workers increases.

\footnotetext{
12 The methodology may be subject to endogeneity. The baseline regression though seems robust to lagging independent variables, including time fixed effects and other variables, see discussion on robustness.

13 The panel is slightly unbalanced. For China the sample spans 1985-2010.

${ }^{14}$ The choice of the panel is constrained by data availability. As we aim to examine the impact of long-run structural trends on inequality we select the panel to have sufficient long time spans for each country. This reduces the number of countries in the sample.
} 
In addition, demand-side factors and differences in quality of education further complicate the relationship.

\section{The policy variables focus on the potential role for fiscal policy and can be aggregated into three main groups: revenue, expenditure and redistribution.}

- Revenue variables include individual income tax revenue in percent of GDP and property tax revenue in percent of GDP.

- Expenditure variables include public spending on health and social protection in percent of GDP. While spending on health and social insurance provision should decrease inequality (Gradstein and Justman, 1997; Benabou, 2000, 2002), it crucially depends on its coverage and targeting (Alesina, 1998; Davoodi et al., 2003; Rhee et al., 2014).

Furthermore, second round effects may exist, offsetting the equalizing effect through higher market inequality (Chu et al., 2000).

- Redistribution is approximated by the difference between the gini index before (Market Gini) and after transfers and taxes (Net Gini). This variable is used to both measure the efficiency with which policies reduce inequality controlling for the level of spending or tax revenue as captured by other policy variables but also to capture other fiscal policies not explicitly included in the regression.

Robustness checks suggest that structural trends are captured well. We have done four main robustness checks, by including the sum of exports and imports over GDP to capture trade openness ${ }^{15}$, GDP per capita and its square to proxy technological change (Jaumotte et al. 2013) and productivity growth, the shadow fed funds rate ${ }^{16}$ to capture global liquidity conditions and including directly time fixed effects. However, these variables do not change meaningfully the baseline results which suggests that they are likely correlated and possibly captured by the other structural variables already included in the regression. For example, trade openness is likely strongly correlated with the share of industry in the economy. GDP per capita is often used to capture the Kuznet's curve ${ }^{17}$. However, we already capture this process through the structural variables, crucially urbanization that has been documented as a key contributing factor for the Kuznets effect (Dimou 2008, Henderson 2003).

Results

${ }^{15}$ Also proxying for capital openness as in Furceri and Loungani (2018).

${ }^{16}$ From Wu and Xia (2016), available from www.frbatlanta.org/cqer/research/shadow rate.aspx?panel=1. Lower global funding costs could lead to greater availability of domestic credit which has been shown to be another driver of inequality (de Haan and Sturm, 2016).

${ }^{17}$ The relationship between economic growth and inequality is often thought to follow an inverted u-shape form, described by Kuznets (1955). However, it needs to be noted that the existing evidence on the Kuznets hypothesis is, at best, inconclusive (Barro 2008; Kanbur, 2000; Cornia et al., 2004, and references therein). 
The regression captures well the past rapid increase in China's inequality and indicates that it was higher than that suggested by structural and macro factors since 2002. In general, the regression's fitted values track China's actual net Gini index only for the period between 1990 and 2002. In the earlier period, actual inequality was lower than implied by the regression, while recently inequality has been above the fitted values. The regression explains close to 16 points increase in the net Gini from 1985 to 2010 , compared to the actual change of around 22 points (from 29 to 51). Thus, while inequality appears "too high" after 2002, much of the rise in the last two decades is in line with the experience in other countries facing the same circumstances.

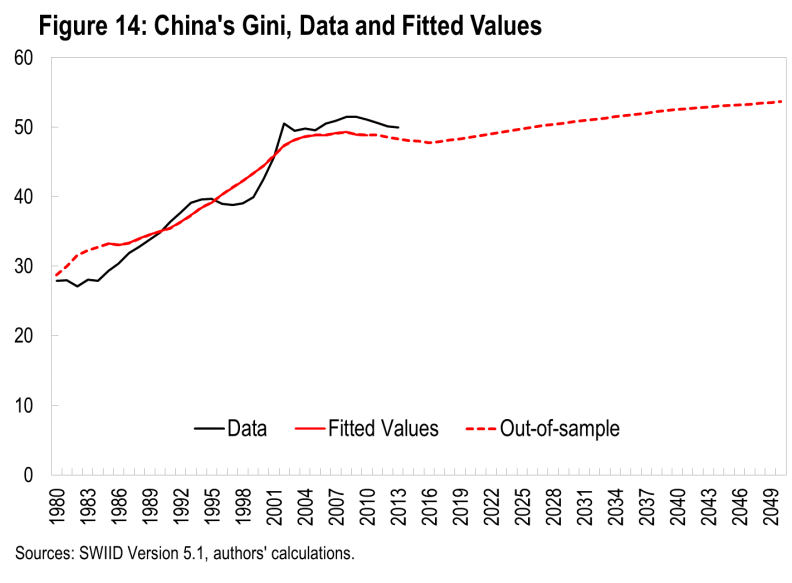

China's rising inequality in the last decades can be crucially tied to structural factors such as urbanization, ageing and sectoral rebalancing, with policies not providing enough of an offset. Structural factors explain most of rise in inequality until 2010.

- $\quad$ The regression suggests that urbanization played a key role contributing to rising inequality in 1985-2010. The share of the population in urban areas rising from 23 percent in 1985 to 51 percent in 2010 implied an increase of 20.5 Gini points over the same time period, reflecting the rising rural-urban divide until about 2008 (see Section IV). In addition, this possibly reflects rising inequality within urban areas caused by rapid urbanization and the lack of adequate safety nets for migrants. ${ }^{18}$

- Demographics tied to the sharp fall in fertility and rapid aging contributed 4.4 points to the rise in the net Gini index. This likely reflects increased income inequality among individuals as they grow older and the lack of an adequate safety net for the elderly. While low fertility could imply less inequality as household income is spread among fewer members it also implies reduced support from the younger generation to older generations.

- Offsetting these contributors leading to widening inequality, rebalancing in the form of sectoral changes - the move from employment in agriculture to industry and services - and improvements in tertiary education attainment contributed to a combined decline of 7.3 Gini points in inequality. As found previously, sectoral changes tend to reduce wage differentials between sectors. This is likely due to general equilibrium effects as workers move into sectors with higher wages, thereby reducing labor supply in lower paying sectors in turn increasing wages there. Within sectors, there might be increasing inequality as found in section IV, but it appears to be offset by the between-sector effects.

\footnotetext{
${ }^{18} \mathrm{We}$ interpret these results as evidence for the Kuznets effect. Urbanization is related to inequality with the expected inverted U-shape. If per capita GDP and its square alone are used as regressors in our setting, we recover the basic Kuznets effect that GDP per capita relates to inequality following an inverted U-shape.
} 
The role of policies in containing the rise in inequality in this period was modest at around 2 Gini points.
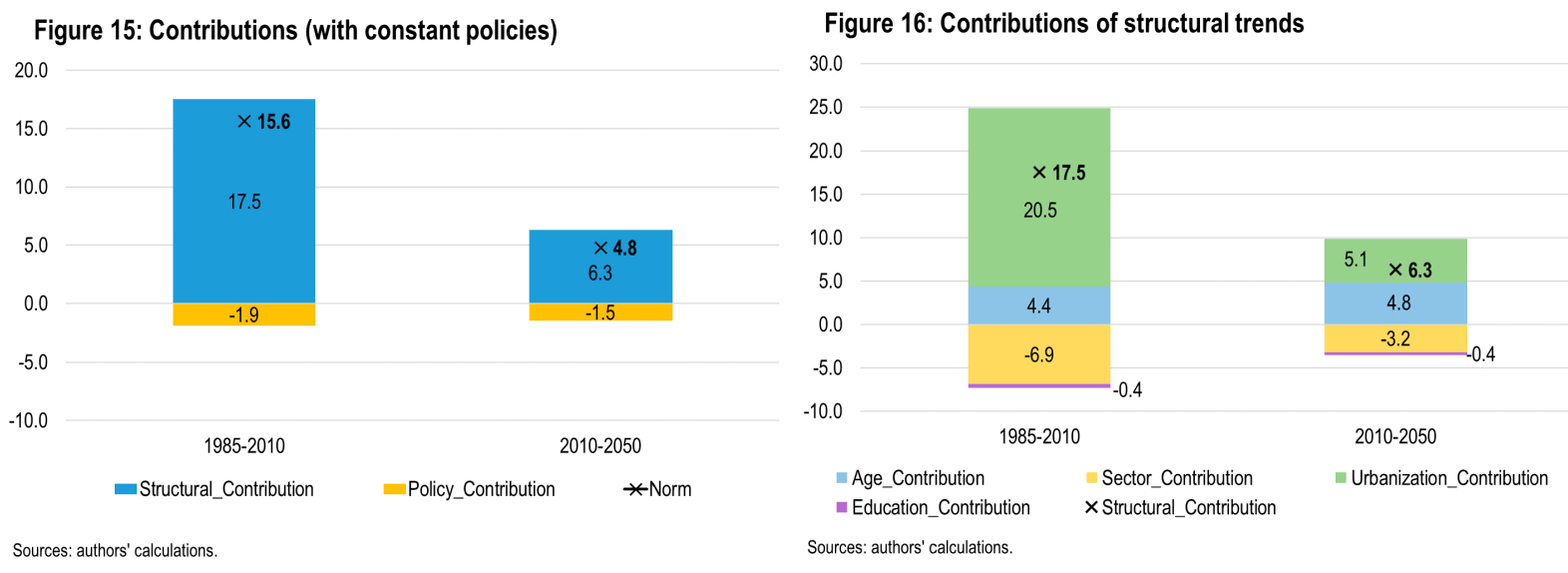

Going forward, inequality will rise further without policy changes, on account of continued urbanization and demographic changes. We use projections of demographic change, urbanization, education attainment and sectoral transformation ${ }^{19}$ and keep all other variables (policies) constant. We find that China's fitted net Gini index rises 4.8 points (2.6 Gini points compared to the observed value in 2010) in the projection period of 2010-2050 driven chiefly due to aging $(+4.8)$ and urbanization $(+5.1)$, although note the latter is much less important than in 1985-2010. Rebalancing away from agriculture and industry reduces inequality by 3.2 Gini points. Tertiary educational attainment continues to lower inequality marginally as linear and quadratic effects are almost offsetting each other. Policies are assumed constant from the latest observation and thus cannot play much of a role in line with past experience (contribution of -1.5 point to the net gini index in 1985-2010), although policies have become more equality-friendly of late.

Fiscal policy is found to be a potentially powerful tool in reducing inequality. Several

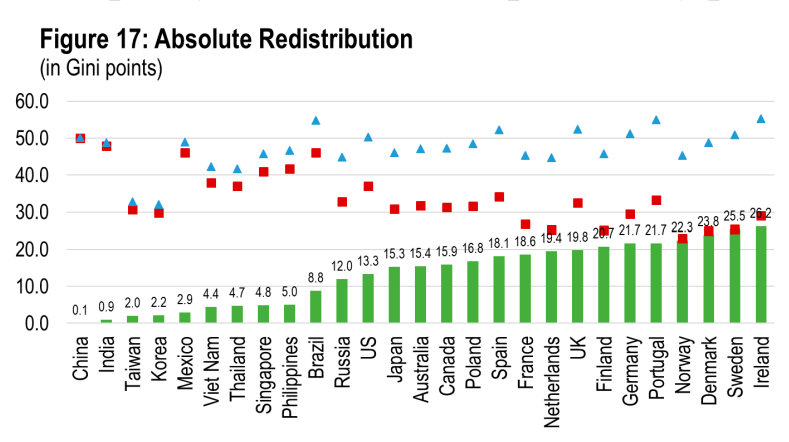

- Absolute Redistribution (Difference between Net and Market Gini)

- Net Gini (After taxes and transfers)

$\triangle$ Market Gini (Before Taxes and Transfers) policies are significantly related to inequality in the panel regression. The regression includes health and social protection expenditure to GDP on the expenditure side and individual income tax and property tax revenues to GDP on the revenue side. It also includes the extent of redistribution proxied by the difference between the market and the net Gini indices

Sources: SWIID Version 5.1

\footnotetext{
${ }^{19}$ Demographics and urbanization from UN, education attainment from Barro and Lee (2013) and sectoral change derived from IMFs own projections until 2030 and gradually extrapolated thereafter to reach 2 percent of employment in agriculture and about 25 percent in industry with the remainder in services.
} 
(see figure 17). ${ }^{20}$ The tax variables are the only policy variables that are not significant in the regression. Given the limited role fiscal policy has played in moderating income inequality in China to date ${ }^{21}$, adjustments in fiscal policy promise to be an important instrument in addressing inequality developments.

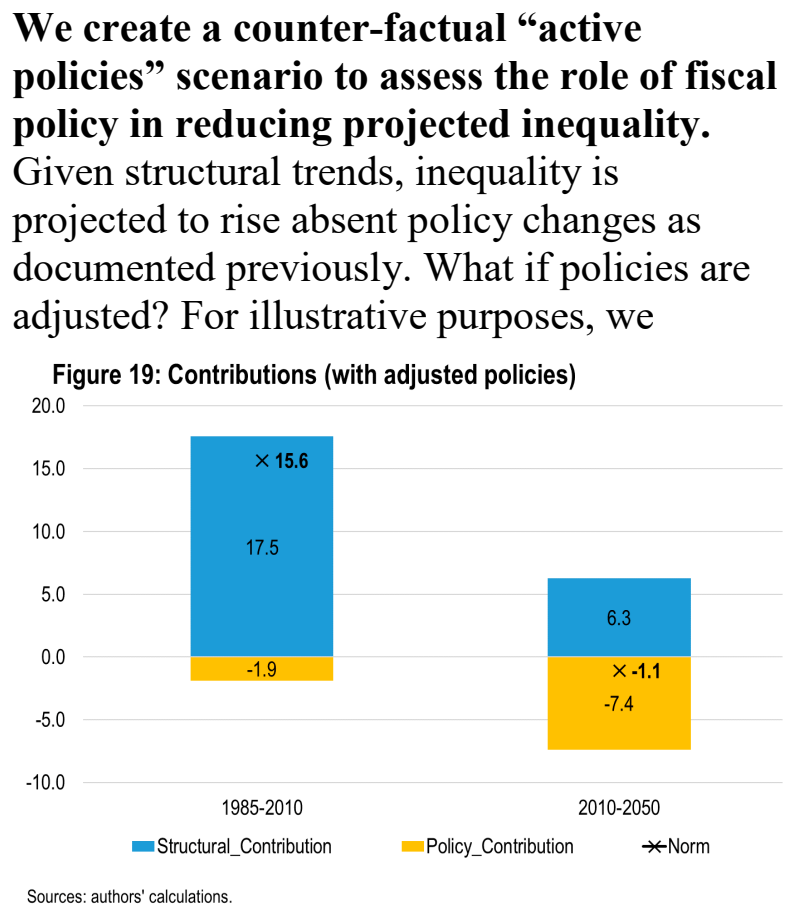

We create a counter-factual "active policy in reducing projected inequality. Given structural trends, inequality is projected to rise absent policy changes as documented previously. What if policies are ajusted? For illustrative purposes, we

assume a gradual adoption of fiscal policies that takes China from current levels to reach the levels of the most proactive countries of the G7 by $2050 .{ }^{22}$ Thus the exercise looks at a counter-factual projection where China is gradually raising its taxes and expenditures and computes the associated impact on inequality.

More proactive policies can meaningfully reduce inequality. Under the "active policies" scenario, inequality slightly declines after 2010 rather than increasing as was the case under

\footnotetext{
${ }^{20}$ Given its definition, one would expect the coefficient of redistribution being close to negative one. In the regression it is however closer to zero. Two different reasons could explain this. First, some measures of redistribution can affect incentives to work, save and invest and therefore the market Gini. Second, the measure of redistribution is likely to be correlated with other explanatory variables, although its function is to capture inequality-reducing policies beyond those explicitly controlled for in the regression.

${ }^{21}$ Similar to figure 17, Zhuang and Li (2016) find that China's post-tax Gini coefficient is only $3 \%$ lower than its pre-tax Gini coefficient, compared to average reduction of over $30 \%$ in OECD countries.

${ }^{22}$ This assumption is consistent with the goals set out in the $19^{\text {th }}$ Party Congress of achieving high-income status by 2025, the average level of OECD countries by 2035 and closing the ratio of Chinese to U.S. income per capita to only half by 2050 . We take the mean policy level in 2010 for the top half of the G7 excluding Germany which is not included in the panel.
}

(continued...) 
unchanged policies. ${ }^{23}$ The full range of policies - tax changes, expenditure increase and redistribution - contributes significantly to reducing inequality, with the largest effect coming from social protection spending and redistribution. While this exercise suggests that inequality might be rising further and even substantive policy efforts will only slightly decrease the predicted Gini coefficient, it is important to note that it would still imply a decrease of 3 Gini points compared to the observed Gini coefficient in 2010. In addition, this cross-country analysis does not include variables with regards to the inclusiveness of policies due to insufficient data availability. Variables of this kind would likely suggest a larger role of policies for reducing inequality. For example, policies that increase health care coverage have likely a stronger impact on reducing inequality compared to policies that increase health care spending while keeping coverage at the same level.

\section{WHAT ROLE CAN FISCAL POLICY PLAY IN REDUCING INEQUALITY?}

Given the possibly large role of policies, several reforms could be envisaged to make fiscal policy more inclusive, both on the tax and expenditure side.

\section{Tax reforms to boost inclusiveness}

The composition of taxes in China could rely more on direct taxes and less on indirect taxes, which could improve progressivity. The VAT and other taxes on goods and services account for about half of tax revenues in China compared to one third in OECD countries (Figure 21). Crucially, revenues from PIT contribute only around 5 percent of total revenues, a much lower share than the OECD average of 25 percent. Increasing the reliance on PIT, which more easily accommodates a progressive structure, could allow China to improve redistribution through the tax system.

\section{The design of direct taxes such as the PIT and social security contributions could} also be improved. While the PIT in China already embeds a progressive schedule with marginal rates increasing with income from 3 to 45 percent, in practice very few taxpayers pay any PIT at all. The top marginal rate applies only to very high incomes in excess of 35 times the national average wage, or 15 times the average urban wage. In contrast, top marginal tax rates in OECD countries are imposed on

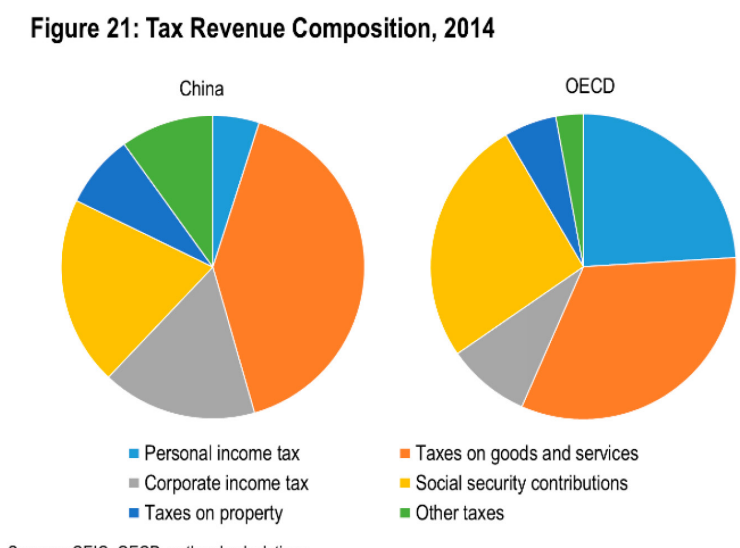
individual income starting at around four times the national average wage on average. Lowering the current high basic personal allowance, transforming it into a tax credit, and redesigning the tax brackets would ensure

\footnotetext{
${ }^{23}$ The projection period starts in 2010 , because some data is only available until this point. However, where
} available we use the actual data and start projecting from the latest actual data available. 
that middle and high income households with higher ability to pay contribute more to financing the national budget and the provision of public goods.

\section{Social security contributions and the PIT generate a strongly regressive tax schedule, exacerbating inequality. In} addition to the PIT, employees are also required to pay social security contributions for pension, unemployment and health insurance. While a nominal flat rate is applied to wages, in practice a minimum employee contribution is required based on some imputed value of earnings. It is estimated that around 30 percent of the urban labor force earns below this imputed value in several large cities (Cai, Du, and Wang 2011) The average effective tax rate that results from this policy leads to prohibitively high tax rates for the lowest earners. Combined with the PIT, both taxes generate a strongly regressive tax schedule, which exacerbates income inequality (Figure 22). Therefore, imputed minimum earnings for social security contributions should be removed, as this would not only contribute to more equitable direct taxes, but would also improve incentives for workers to join the formal sector.

Property and wealth taxes remain limited in China. Such taxes are broadly viewed as progressive, because high-income households usually tend also to have more property and wealth. They are also considered to be a very efficient source of tax revenues, as they tend to be the least distortive to growth (Norregaard 2013). Consideration should therefore be given to adopt a recurrent market-value based property tax, which would have the added benefit of supporting ongoing urbanization and intergovernmental fiscal reforms.

\section{Expenditure side reforms to boost inclusiveness}

\section{While important gains have been made in recent years, China still lags other emerging economies and OECD countries in public spending on} education, health and social assistance. Beyond the negative impact on current levels of inequality, this also is leaving the country vulnerable to a rapidly aging population, which will further strain public health services budgets and pension funds. In present discounted value, the imbalance of the pension system over the period from 2015-2050 is estimated to be around 125

percent of 2015 GDP (Soto and Gupta 2017).

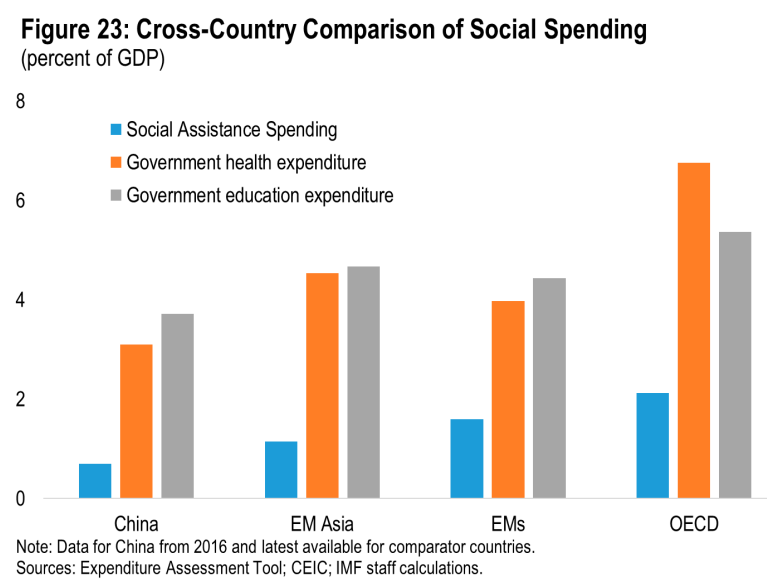
Sources: Expenditure Assessment Tool; CEIC; IMF staff calculations.

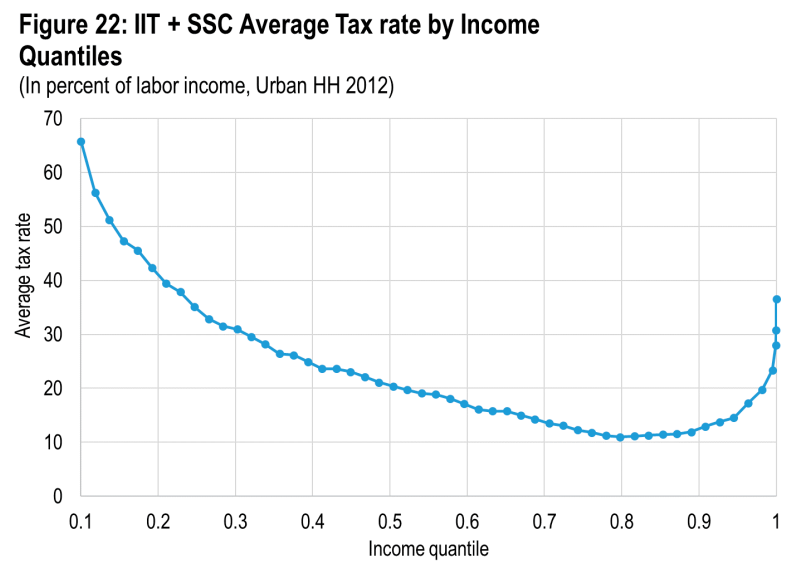


In addition to the low level of social spending, another important dimension is the unequal provision of public services. This is particularly the case for the hukou-or household registration-system. New migrants to urban areas, which are expected to number 300 million over the next two decades, often lack access to social entitlements such as health care, education, and housing due to stringent registration requirements. Liberalizing the residency system, as some provinces have started doing, will allow more migrants to contribute to and benefit from the social safety net. This would reduce disparities and strengthen the redistributive effect of fiscal policy.

\section{Provincial and regional inequalities in} public service provision and access have also been growing in recent years, with richer provinces outpacing poorer areas. This can be seen for instance in access to health care, as the disparity in the number of hospital beds per 1000 people has increased significantly between 2004 and

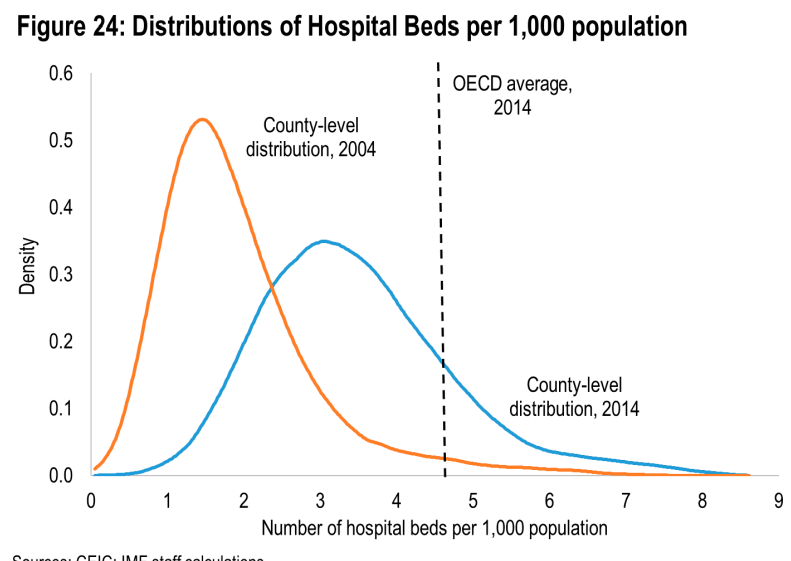

Sources: CEIC; IMF staff calculations. 2014 (Figure 24). Higher income regions have also benefitted disproportionately from the overall increases. The recently announced reform plans by the State Council to address intergovernmental relations will reduce regional disparities by increasing transfers to poorer regions. This will require an increase in the pool of funds used to finance equalization grants and more reliance on a rules-based system, as opposed to the ad hoc process currently used in the annual budget preparation (Liu, Martinez-Vazquez and Qiao, 2014). Reforming the overly complex system of conditional transfers, with a stronger focus on outcomes as opposed to inputs, should also support improvement in public service delivery. Finally, a recentralization of social insurance would also improve equality, risk sharing and labor mobility.

\section{Conclusion}

Over the past two decades, China has seen a sharp reduction of poverty, but also a substantial increase of inequality. Income inequality in China increased sharply from the early 1980s and rendered China among the most unequal countries in the world by 2013 . This trend has started to reverse as China has experienced a modest decline in income inequality since 2008. In addition, despite significant progress China also faces considerable inequality of opportunities, such as uneven completion of higher tertiary education, gaps in access to certain financial services and unemployment insurance coverage.

We identify various drivers behind these trends in inequality, including structural changes such as urbanization and aging and, more recently, policy initiatives to combat it. Our empirical analysis suggests that the increase in income inequality was driven by various factors, including differences in education and the skill premium, and structural factors such as urbanization and population aging. The recent decline in income inequality is 
found to be broad based, driven by a decrease in the skill premium, and declines in geographical and inter-sectoral income gaps. Policies have also become more equalizing of late.

Inequality will likely rise further without policy changes, on account of continued urbanization and demographic changes. Simulating structural changes until 2050, we find that aging and urbanization are likely to drive inequality higher and that policies will need to play an important role in curbing inequality in the future. In particular, fiscal policy reforms have the potential to enhance inclusiveness and equity. Our results suggest that the full range of policies - tax changes, expenditure increase and redistribution - could contribute significantly to reducing inequality, with the largest effect coming from social protection spending and redistribution.

Given the possibly large role of policies, several reforms could be envisaged to make fiscal policy more inclusive, both on the tax and expenditure side. On the revenue side, measures should include increasing the progressivity of social security contributions and of personal and property taxes. On the spending side, social expenditure will need to be boosted to ensure sufficient protection against income and health risks and to ensure equal access to public services across provinces and regardless of residency status. 


\section{References}

Alesina, A., and Rodrik, D., 1994, "Distributive Politics and Economic Growth," Quarterly Journal of Economics, 109(2), pp.465-90.

Alesina, A., and Perotti, R., 1996, "Income Distribution, Political Instability, and Investment", European Economic Review, 40(6): p. 1203-1228.

Alesina, A., 1998, "The political economy of macroeconomic stabilisations and income inequality: myths and reality," In: Tanzi, V., and Chu, K. (eds), Income Distribution and High-Quality Growth, MIT Press, London.

Alvaredo, F., Atkinson, A., Piketty, T., Saez, E., and Zucman, G., "WID- The World Wealth and Income Database", http://www.wid.world/, 24/04/2017.

Barro, 2008, "Inequality and Growth Revisited," Asian Development Bank Working Paper Series on Regional Economic Integration, No. 11.

Barro, R. and Lee, J., 2013, "A New Data Set of Educational Attainment in the World, 19502010." Journal of Development Economics, vol 104, pp.184-198.

Benabou, R., 2000, "Unequal Societies: Income Distribution and the Social Contract," American Economic Review, 90(1), pp.96-129.

Benabou, R., 2002, "Tax and Education Policy in a Heterogeneous-Agent Economy: What Levels of Redistribution Maximize Growth and Efficiency?" Econometrica, 70(2), pp.481517.

Banerjee, A., and Newman, A., 1993, "Occupational choice and the process of development" Journal of Political Economy, 101(2), pp.274-298.

Behrens, K., and Robert-Nicoud, F., 2014, "Survival of the Fittest in Cities: Urbanization and Inequality," The Economic Journal, vol 124, pp1371-1400

Berg, A., and Ostry, J., 2011, "Inequality and Unsustainable Growth: Two Sides of the Same Coin?” IMF Staff Discussion Note 11/08, International Monetary Fund, Washington.

_ , and Zettelmeyer, J., 2012, "What Makes Growth Sustained?" Journal of

Development Economics, 98(2), pp.149-66.

Cai, F., Du, Y., and Wang, M. (2011), “Overview of China's Labor Market,” Institute of Population and Labor Economics, China Academy of Social Sciences, Beijing.

Cai, Meng and Yue, Ximing, 2016, Redistributive Role of Public Transfer on Inequality in China, CIID working paper No.53.

Cornia, G., Addison, T., and Kiiski, S., 2004, "Income distribution changes and their impact in the post-Second World War period," in Cornia, G. (ed), Inequality, Growth and Poverty in the Era of Liberalization and Globalization, Oxford University Press/ United Nations University, World Institute for Economics Research.

Chan, W. K., 2015, "Higher Education and Graduate Employment in China: Challenges for Sustainable Development", Higher Education Policy, 28 (1), pp. 35-53. 
Chu, K., Davoodi, H., and Gupta, S., 2000, "Income distribution and tax and government spending policies in developing countries," IMF Working Paper 00/62, International Monetary Fund, Washington.

Dabla-Norris, E., Kochhar, K., Ricka, F., Suphaphiphat, N., and Tsounta, E., 2015, “Causes and Consequences of Income Inequality: A Global Perspective" IMF Staff Discussion Note 15/13, International Monetary Fund, Washington.

Davoodi, H., Tiongson, E., and Asawanuchit, S., 2003, "How useful are benefit incidence analyses of public expenditure and health spending?” IMF Working Paper 03/227, International Monetary Fund, Washington.

Deaton A. and Paxson, C. H. 1994, "Intertemporal Choice and Inequality," Journal of Political Economy, 102(3), pp. 437-67.

Deaton A. and Paxson, C. H. 1997, "The Effects of Economic and Population Growth on National Saving and Inequality," Demography, 34(1), pp. 97-114.

De Gregorio, J., and Lee, J., 2002, "Education and Income Inequality: New Evidence from Cross-Country Data," Review of Income and Wealth, 48(3), pp.395-416.

de Haan, J. and J.-E. Sturm, 2016, "Finance and Income Inequality: A Review and New Evidence," CESifo Working Paper Series, \#6079, CESifo Group Munich

Dimou, M. (2008), "Urbanisation, Agglomeration Effects and Regional Inequality: an introduction," Région et Développement $n^{\circ} 27$.

Dollar, D., 2007, "Poverty, inequality and social disparities during China's economic reform," Policy Research Working Paper 4253, World Bank, Washington.

Easterly, W., 2007, “Inequality Does Cause Underdevelopment: Insights from a New Instrument," Journal of Development Economics, 84(2), pp.755-76.

Eichen, M. and M. Zhang (1993), “Annex: The 1988 Household Sample Survey-Data Description and Availability," in K. Griffin and R. Zhao, eds., The Distribution of Income in China, 331-346, New York: St. Martin's Press.

Furceri, D. and and P. Loungani, 2018. "The distributional effects of capital account liberalization," Journal of Development Economics, vol. 130(C), pp. 127-144

Galor, O., and Zeira, J., 1993, “Income distribution and Macroeconomics,” Review of Economic Studies, 60, pp.35-52.

Gradstein, M., and Justman, M., 1997, "Democratic Choice of an Education System: Implications for Growth and Income Distribution,” Journal of Economic Growth, 2(2), pp.169-183.

Griffen, K. and R. Zhao, eds. (1993), The Distribution of Income in China, Basingstoke: Macmillan.

Gustafsson, B., S. Li, and T. Sicular, eds. (2008), Inequality and Public Policy in China, New York: Cambridge University Press.

Heckman, J., and Yi, J., 2012 "Human Capital, Economic Growth, and Inequality in China," NBER Working Paper 18100. 
Henderson J.V., 2003, "The urbanization process and economic growth : the sowhat question," Journal of Economic Growth, 8, 47-71.Higgins, Matthew. 1998. "Demography, National Savings, and International Capital Flows," International Economic Review, Vol. 39, No. 2, 343-369.

Hofman, B., and Guerra, S. C., (2007), "Ensuring Inter-Regional Equity and Poverty Reduction," in Fiscal Equalization: Challenges in the Design of Intergovernmental Transfers, edited by Jorge Martinez-Vazquez and Bob Searle, 31-60. Amsterdam: Springer.

Hoken, Hisatoshi, and Hiroshi Sato. Public Policy and the Long-Term Trend in Inequality in Rural China, 1988-2013. CIID working paper No. 57, 2016.

Jain-Chandra, S., Kinda, T., Kochhar, K., Piao, S., and Schauer, J. (2016), "Sharing the Growth Dividend: Analysis of Inequality in Asia", IMF Working Paper, WP/16/48.

Jaumotte F., S. Lall and C. Papageorgiou, 2013, "Rising Income Inequality: Technology, or Trade and Financial Globalization?," IMF Economic Review, vol. 61(2), pp. 271-309.

Kanbur, R., 2000, “Income Distribution and Development”, Handbook of Income Distribution: Volume 1. Edited by Atkinson, A. and Bourguignon, F.

Kanbur, R., Wang, Y., Zhang, X., 2017, “The Great Chinese Inequality Turnaround”, CEPR Discussion Paper No. 11892.

Kong, Sherry Tao (2010), "Rural-Urban Migration in China: Survey Design and Implementation," in X. Meng, C. Manning, S. Li, and T. N. Effendi, eds., The Great Migration: Rural-Urban Migration in China and Indonesia, 135-150, Northampton, MA: Edward Elgar.

Knight, J., Deng, Q., and Li, S., 2016, “China's Expansion of Higher Education: The Labour Market Consequences of a Supply Shock”, CSAE Working Paper WPS/2016-04, Oxford: Centre for the Study of African Economies.

Knight, J., and Sabot, R., 1983, 'Educational Expansion and the Kuznets Effect,' American Economic Review, 73(5), pp.1132-1136.

Kuznets, S., 1955, "Economic Growth and Income Inequality," American Economic Review, 45(1), pp.1-28.

Lam, W.R., and Wingender, P. (2015), "China: How Can Revenue Reforms Contribute to Inclusive and Sustainable Growth?” IMF Working Paper No. 15/66 (Washington: International Monetary Fund).

Li, S., and C. Luo. 2010. Re-Estimating the Income Gap between Urban and Rural Households in China. In M. Whyte, ed. One Country, Two Societies: Rural-Urban Inequality in Contemporary China. Cambridge, MA: Harvard University Press.

Li, S., Luo, C., Wei, Z., and Yue, X. (2008), “Appendix: The 1995 and 2002 Household Surveys: Sampling Methods and Data Description," in B. Gustafsson, S. Li, and T. Sicular, eds., Inequality and Public Policy in China, 337-353, New York: Cambridge University Press. 
Li, S., G. Ma, and J. Xu, 2012, “The Income Redistribution Effect of China's Personal Income Tax: What the Micro Data Say?" Discussion paper. China Institute of Income Distribution, Beijing Normal University.

Li, S., H. Sato, and T. Sicular, eds. 2013. Inequality in China: Public Policy and the Pursuit of a Harmonious Society. Cambridge, UK: Cambridge University Press.

Li, S., Wan, G., and Zhuang, J., 2014, "Income inequality and redistributive policy in the People's Republic of China," In: Kanbur, R., Rhee, C. and Zhuang, J. (eds), Inequality in Asia and the Pacific: Trends, Drivers and Policy Implications, Routledge: London.

Li, S., and S. Yang. 2009. Effect of China's Urban Minimum Living Security System on Income Distribution and Poverty. China Population Science. 5. pp. 19-27.

Lin, C., and Yun, M., 2016, “The Effecs of the Minimum Wage on Earnings Inequality: Evidence from China”, IZA Discussion Paper No. 9715.

Lin, T., J. Zhuang, D. Yarcia, and F. Lin, 2010, “Decomposing Income Inequality: People's Republic of China, 1990-2005”, In J. Zhuang, ed. Poverty, Inequality, and Inclusive Growth in Asia: Measurement, Policy Issues, and Country Studies. Manila: ADB and London: Anthem Press.

Liu, L., 2009, "Skill Premium and Wage Differences: The Case of China", Conference paper for the Second International Symposium on Knowledge Acquisition and Modeling.

Liu, Y., Martinez-Vazquez, J., and Qiao, B. (2014). “Falling Short: Intergovernmental Transfers in China," Public Finance and Management, 14 (4), 374-398.

Liu, Z., 2005, "Institution and inequality: the hukou system in China," Journal of Comparative Economics, 33, pp.133-157.

Luo, Li, Sicular, Deng, and Yue (2013), " Appendix I: The 2007 Household Surveys: Sampling Methods and Data Description", in Shi Li, Sato H., Sicular T. Rising Inequality in China: Challenges to a Harmonious Society. Cam-bridge University Press.

Norregaard, J., (2013), “Taxing Immovable Property: Revenue Potential and Implementation Challenges," IMF Working Paper No. 13/129 (Washington: International Monetary Fund).

OECD (2016), “2017 Economic Review -China”.

Ostry J. D., A. Berg and S. Kothari, 2018, "Growth-Equity Trade-offs in Structural Reforms,” IMF Working Paper No. 18/5 (Washington: International Monetary Fund)

Ostry, J. D., Berg, A., and Tsangarides, C., 2014, "Redistribution, Inequality, and Growth," IMF Staff Discussion Note 14/02, International Monetary Fund, Washington.

Perotti, R., 1996, "Growth, Income Distribution, and Democracy: What the Data Say," Journal of Economic Growth, 1(2), pp.149-87.

Piketty, T., Yang, L., and Zucman, G., 2017, “Capital Accumulation, Private Property and Rising Inequality in China, 1978-2015”, WID.world working paper series N. 2017/6.

Posner, R., 1997, "Equality, Wealth, and Political Stability", The Journal of Law, Economics, and Organization, Volume 13, Issue 2, pp. 344-365. 
Rajan, R.G., 2010, “Fault Lines”, Princeton, New Jersey: Princeton University Press.

Rauch, J. E. 1993, “Economic Development, Urban underemployment, and Income Inequality," Canadian Journal of Economics 26, 901-18.

Ravallion, M., and S. Chen, 2007, “China's (Uneven) Progress against Poverty”, Journal of Development Economics, 82 (1), pp. 1-42.

Rhee, C., Zhuang, J., Kanbur, R., and Felipe, J., 2014, "Confronting Asia's rising inequality: policy options," In: Kanbur, R., Rhee, C. and Zhuang, J. (eds), Inequality in Asia and the Pacific: Trends, Drivers and Policy Implications, Routledge: London.

Riskin, C., R. Zhao, and S. Li, eds. (2001), China's Retreat from Equality: Income Distribution and Economic Transition, Armonk, New York: M. E. Sharpe.

Shi, L., Wan, G., Zhuang J. (2014), "Income Inequality and Redistributive Policy in the People's Republic of China", published in "Inequality in Asia and the Pacific. Trends, Drivers and Policy Implication".

Solt, F., 2009, "Standardizing the World Income Inequality Database," Social Science Quarterly, 90(2), pp.231-42.

Solt, F., 2016. “The Standardized World Income Inequality Database.” Social Science Quarterly 97. SWIID Version 5.1, July 2016.

State Council of the People's Republic of China, 2011, “The Twelfth Five Year Plan for National Economic and Social Development of the People's Republic of China (20112015)" (in Chinese), http://news.sina.com.cn/c/2011-03-17/055622129864.shtml.

United Nations, Department of Economic and Social Affairs, Population Division (2015). World Population Prospects: The 2015 Revision, DVD Edition.

United Nations, Department of Economic and Social Affairs, Population Division (2014). World Urbanization Prospects: The 2014 Revision, CD-ROM Edition.

Wang, X. and Herd, R. (2013), “The System of Revenue Sharing and Fiscal Transfers in China," OECD Economics Department Working Paper 1030, OECD Publishing, Paris.

World Bank and the People's Bank of China (2018), "Toward Universal Financial Inclusion in China : Models, Challenges, and Global Lessons," World Bank, Washington, DC.

World Inequality Database on Education, http:/www.education-inequalities.org/.

Wu, J. C., and F. D. Xia, 2016 "Measuring the Macroeconomic Impact of Monetary Policy at the Zero Lower Bound," Journal of Monay, Credit and Banking, 48(2-3), pp. 253-291.

Zhang, X., and Kanbur, R., 2005, "Spatial inequality in education and health care in China," China Economic Review, 16, pp.189-204.

Zhuang, J., P. Vandenberg, and Y. Huang. 2012. Growing beyond the Low-Cost Advantage: How the People's Republic of China Can Avoid the Middle-Income Trap. Manila: ADB.

Zhuang, J., and Li, S. (2016), "Understanding Recent Trends in Income Inequality in the People's Republic of China”, ADB Economics Working Paper Series. 

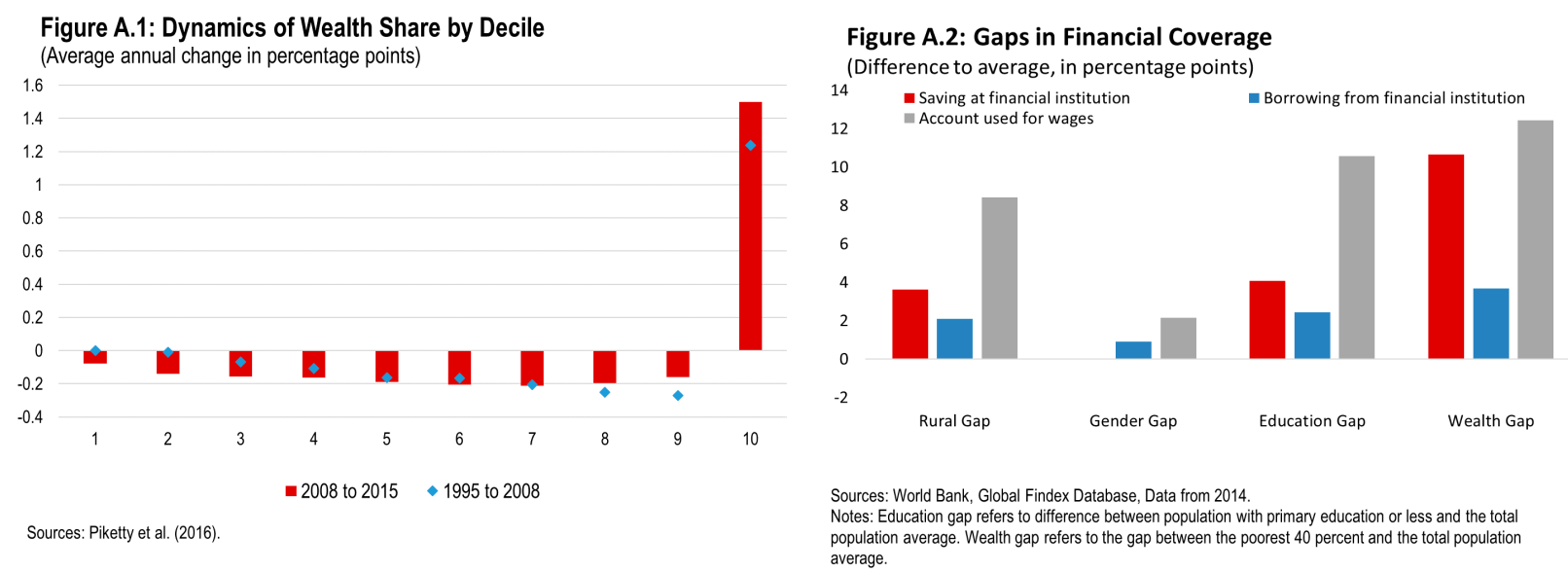

Appendix A2: Description of income inequality measures and data

\section{SWIID Gini estimates:}

This dataset aims to combine two major aspects- "maximizing the comparability of income inequality data while maintaining the widest possible coverage across countries and over time." It reports Gini coefficients for 174 countries from 1960 to the present. Solt uses the Luxembourg Income Study as its standard, as it is based on income surveys only and aims to achieve the highest level of harmonization. Further values are generated using model-based imputation using various supplementary data sources (including United Nations University's World Income Inequality Database, the OECD Income Distribution Database, national statistical offices et al.). Still, major issues remain as questionnaires, definitions and quality of data differ across sources and countries. For a further discussion see Solt (2016).

\section{Ravallion and Chen (2007) Gini estimates:}

The Gini coefficients are calculated using the Rural Household Surveys and the Urban Household Surveys of China's National Bureau of Statistics. To maximize accuracy of the measure the authors impute values for income from own production and account for change in valuation methods in 1990 when public procurement prices were replaced by local selling prices. They also calculate a second Gini estimate accounting for urban-rural cost-of-living differences. This adjustment lowers the level of the Gini coefficient, but the trend remains similar (see figure A2.1). Various caveats remain as sample sizes for the early surveys were smaller, sample frames do not account for rural-urban migrants and access to the data was only limited. It also does not impute rents for owner-occupied housing, given the thinness of housing markets. For a further discussion see Ravallion and Chen (2007).

\section{NBS estimates:}

The NBS started releasing its own estimates of Gini coefficients in 2013, including retrospective estimates. These estimates are based on the Rural and Urban Household Surveys and aims to integrate these with a new "urban-rural integrated" sampling framework. 
It also employed data from personal income tax records to correct for biases. Weaknesses of the data included the lack of imputing in-kind compensation and imputed rents from owneroccupied housing. In addition, the income concept has been broadened over time. While this improves accuracy of inequality measures over time it weakens inter-temporal comparability. In particular, major changes since 2013 included imputation of rents in urban income and employer contributions to employee benefits. For more information see Gustafsson et al. (2014).

\section{Piketty et al. (2016):}

The authors combine national accounts, survey, wealth and fiscal data. They begin with detailed tabulations published by China's Statistical Bureau, which is based on nationally representative household surveys. They interpolate these and subsequently correct them based on income tax data on high-income taxpayers, given that household surveys often struggle to capture top earners. Finally, they use national accounts and wealth data to correct for tax-exempt capital income, such as undistributed profits of privately-owned corporations or owner-occupied housing. The main shortcoming pointed out by the authors is the lack of highly detailed micro data. For a further discussion see Piketty et al. (2016).

\section{China Household Income Project (CHIP):}

The data used in decomposition analysis are three waves of the China Household Income Project (CHIP) household surveys, 1995, 2007, and 2013. These surveys were carried out as part of a collaborative research project on incomes and inequality in China organized by Chinese and international researchers, with assistance from China's National Bureau of Statistics (NBS). The data have been analyzed by the CHIP project participants and other researchers extensively and resulted in a large number of articles, reports, and books. Descriptions of the CHIP surveys and key findings can be found in Griffin and Zhao (1993), Riskin, Zhao, and Li (2001), Gustafsson, Li, and Sicular (2008), and Li, Hiroshi and Sicular (2013), and can also be accessed at http://www.ciidbnu.org/chip/index.asp?lang=EN.

CHIP has conducted five waves of household income and expenditure surveys, in 1988, 1995, 2002, 2007 and 2013, respectively, covering both rural and urban households. The samples are subsamples of the larger NBS urban and rural household survey samples, selected by systematic sampling method and designed to be representative of China's four distinct regions: large municipalities with provincial status, eastern China, central China, and western China. The 1995 survey used in this paper covered 6929 urban households from 11 provinces and 7998 rural households from 19 provinces; the 2007 survey covered 9999 urban households and 13000 rural households from 17 provinces, and the 2013 survey covered 6762 urban households and 10530 rural households from 15 provinces.

The CHIP survey samples have several characteristics that may lead to an estimation bias if the samples are used without population-based sample weights; for instance, not all provinces are included in the samples, and provincial sample sizes are not proportional to their populations. To address these issues, the CHIP team has developed a weighting scheme based on three levels: urban/rural, provinces, and region (see discussions in Li, Hiroshi and Sicular, 2013). Decomposition analysis in this paper adopts this weighting scheme. 
The CHIP data cover household income, expenditure, and demographic characteristics of household members. The net household disposable income includes imputed subsidies on subsidized rental housing, and imputed value of rental income on owner-occupied housing.

\section{Appendix A3: Theil Estimation Results}

Table 1: Inequality decomposition by education attainment of head of households

\begin{tabular}{|c|c|c|c|c|c|c|}
\hline $\begin{array}{l}\text { Education } \\
\text { attainment }\end{array}$ & 1995 & & 2007 & & 2013 & \\
\hline & $\begin{array}{l}\text { Theil's T } \\
\text { index }\end{array}$ & Share (\%) & Theil's T index & Share (\%) & $\begin{array}{c}\text { Theil's T } \\
\text { index }\end{array}$ & Share $(\%)$ \\
\hline Illiterate & 0.0147 & 4.14 & 0.0078 & 1.99 & 0.0071 & 2.04 \\
\hline Primary & 0.0536 & 15.15 & 0.0290 & 7.37 & 0.0394 & 11.35 \\
\hline Junior middle & 0.1137 & 32.14 & 0.0924 & 23.49 & 0.1024 & 29.51 \\
\hline Senior middle & 0.0745 & 21.05 & 0.0813 & 20.65 & 0.0641 & 18.47 \\
\hline Junior college & 0.0177 & 5.00 & 0.0331 & 8.42 & 0.0214 & 6.17 \\
\hline $\begin{array}{l}\text { Undergraduate } \\
\text { or above }\end{array}$ & 0.0109 & 3.09 & 0.0252 & 6.41 & 0.0217 & 6.25 \\
\hline Within & 0.2852 & 80.57 & 0.2688 & 68.32 & 0.2560 & 73.79 \\
\hline Between & 0.0693 & 19.57 & 0.1251 & 31.80 & 0.0916 & 26.42 \\
\hline Total & 0.3539 & 100.00 & 0.3934 & 100.00 & 0.3469 & 100.00 \\
\hline
\end{tabular}

Table 2: Inequality decomposition by urban/urban

\begin{tabular}{ccccccc}
\hline & 1995 & \multicolumn{3}{c}{2007} & 2013 \\
\hline & $\begin{array}{c}\text { Theil's T } \\
\text { index }\end{array}$ & Share (\%) & Theil's T index & Share (\%) & $\begin{array}{c}\text { Theil's T } \\
\text { index }\end{array}$ & Share (\%) \\
\hline Rural & 0.1064 & 30.07 & 0.0646 & 16.42 & 0.0752 & 21.68 \\
Urban & 0.0878 & 24.82 & 0.1448 & 36.81 & 0.1546 & 44.55 \\
\hline Within & 0.1942 & 54.88 & 0.2094 & 53.23 & 0.2298 & 66.23 \\
Between & 0.1608 & 45.44 & 0.1855 & 47.16 & 0.1184 & 34.12 \\
Total & 0.3539 & 100.00 & 0.3934 & 100.00 & 0.3469 & 100.00 \\
\hline
\end{tabular}

Table 3: Inequality decomposition by province

\begin{tabular}{lcccccccc}
\hline Provinces & 1995 & \multicolumn{3}{c}{ 2007 } & & \multicolumn{2}{c}{2013} \\
& $\begin{array}{c}\text { Theil's } \\
\text { T index }\end{array}$ & $\begin{array}{c}\text { Share } \\
(\%)\end{array}$ & & $\begin{array}{c}\text { Theil's T } \\
\text { index }\end{array}$ & $\begin{array}{c}\text { Share } \\
(\%)\end{array}$ & $\begin{array}{c}\text { Theil's } \\
\text { Index }\end{array}$ & $\begin{array}{c}\text { Share } \\
(\%)\end{array}$ \\
\hline Group_11 & 0.0084 & 2.38 & Group_11 & 0.0058 & 1.47 & Group_11 & 0.0088 & 2.53 \\
Group_13 & 0.0046 & 1.30 & Group_13 & 0.0051 & 1.30 & Group_14 & 0.0102 & 2.93 \\
Group_14 & 0.0072 & 2.03 & Group_14 & 0.0086 & 2.20 & Group_21 & 0.0214 & 6.18 \\
Group_21 & 0.0131 & 3.69 & Group_21 & 0.0118 & 3.00 & Group_32 & 0.0450 & 12.97 \\
Group_22 & 0.0015 & 0.42 & Group_31 & 0.0062 & 1.57 & Group_34 & 0.0177 & 5.10 \\
Group_32 & 0.0203 & 5.73 & Group_32 & 0.0449 & 11.41 & Group_37 & 0.0333 & 9.60 \\
Group_33 & 0.0054 & 1.51 & Group_33 & 0.0242 & 6.16 & Group_41 & 0.0209 & 6.03 \\
Group_34 & 0.0114 & 3.23 & Group_34 & 0.0157 & 3.99 & Group_42 & 0.0158 & 4.56 \\
Group_36 & 0.0014 & 0.40 & Group_35 & 0.0105 & 2.66 & Group_43 & 0.0182 & 5.25 \\
Group_37 & 0.0111 & 3.15 & Group_41 & 0.0265 & 6.74 & Group_44 & 0.0461 & 13.30 \\
Group_41 & 0.0149 & 4.22 & Group_42 & 0.0165 & 4.20 & Group_50 & 0.0099 & 2.85 \\
Group_42 & 0.0178 & 5.04 & Group_43 & 0.0197 & 5.01 & Group_51 & 0.0233 & 6.73 \\
Group_43 & 0.0027 & 0.77 & Group_44 & 0.0434 & 11.04 & Group_53 & 0.0197 & 5.68 \\
Group_44 & 0.0466 & 13.16 & Group_50 & 0.0111 & 2.82 & Group_62 & 0.0089 & 2.56 \\
Group_51 & 0.0451 & 12.75 & Group_51 & 0.0359 & 9.13 & Group_65 & 0.0086 & 2.47
\end{tabular}




\begin{tabular}{|c|c|c|c|c|c|c|c|c|}
\hline Group_52 & 0.0015 & 0.42 & Group_53 & 0.0179 & 4.56 & & & \\
\hline Group_53 & 0.0113 & 3.20 & Group_62 & 0.0087 & 2.20 & & & \\
\hline Group_61 & 0.0013 & 0.37 & & & & & & \\
\hline Group_62 & 0.0059 & 1.68 & & & & & & \\
\hline Within & 0.2316 & 65.44 & Within & 0.3126 & 79.46 & Within & 0.3079 & 88.74 \\
\hline Between & 0.1227 & 34.66 & Between & 0.0805 & 20.47 & Between & 0.0392 & 11.31 \\
\hline Total & 0.3539 & 100.00 & Total & 0.3934 & 100.00 & Total & 0.3469 & 100.00 \\
\hline
\end{tabular}

Table 4: Inequality decomposition by sector

\begin{tabular}{ccccccc}
\hline & 1995 & \multicolumn{3}{c}{2007} & \multicolumn{3}{c}{2013} \\
\hline Sector & $\begin{array}{c}\text { Theil's T } \\
\text { index }\end{array}$ & Share (\%) & $\begin{array}{c}\text { Theil's T } \\
\text { index }\end{array}$ & Share (\%) & $\begin{array}{c}\text { Theil's T } \\
\text { index }\end{array}$ & Share (\%) \\
\hline Not Work & 0.0241 & 6.81 & 0.11 & 29.14 & 0.11 & 30.27 \\
Agriculture & 0.0791 & 22.34 & 0.0179 & 4.55 & 0.0087 & 2.51 \\
Secondary & 0.0617 & 17.42 & 0.0698 & 17.74 & 0.0751 & 21.65 \\
Service & 0.0764 & 21.59 & 0.1280 & 32.54 & 0.1321 & 38.08 \\
\hline Within & 0.2412 & 68.16 & 0.3304 & 83.97 & 0.3210 & 92.51 \\
Between & 0.1137 & 32.14 & 0.0639 & 16.25 & 0.0261 & 7.53 \\
Total & 0.3539 & 100.00 & 0.3934 & 100.00 & 0.3469 & 100.00 \\
\hline
\end{tabular}

\section{Appendix A4: Cross-Country Regression}

The sample includes Argentina, Australia, Brazil, Bulgaria, Canada, China, Denmark, Hungary, India, Italy, Japan, Mexico, Netherlands, New Zealand, Norway, Panama, Philippines, Poland, Portugal, Korea, Singapore, Spain, Sweden, Switzerland, Thailand, the United Kingdom, the United States of America, and Venezuela.

See next page for regression results.

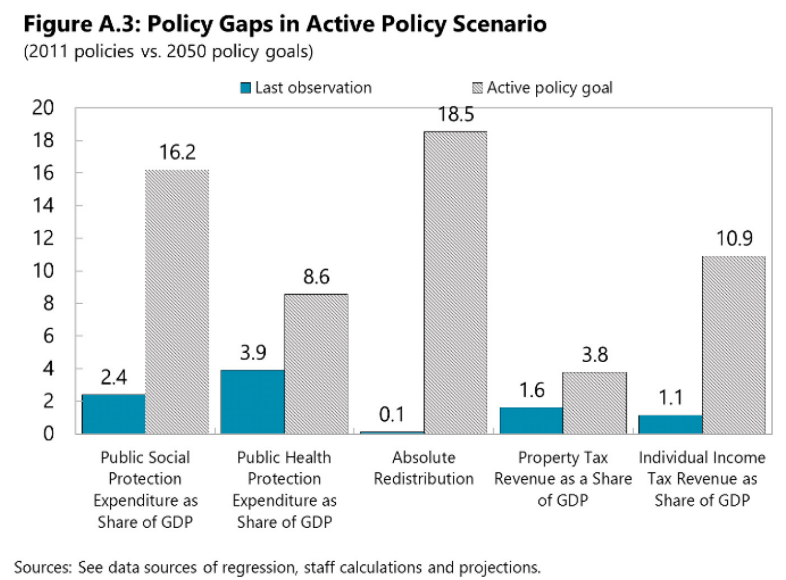




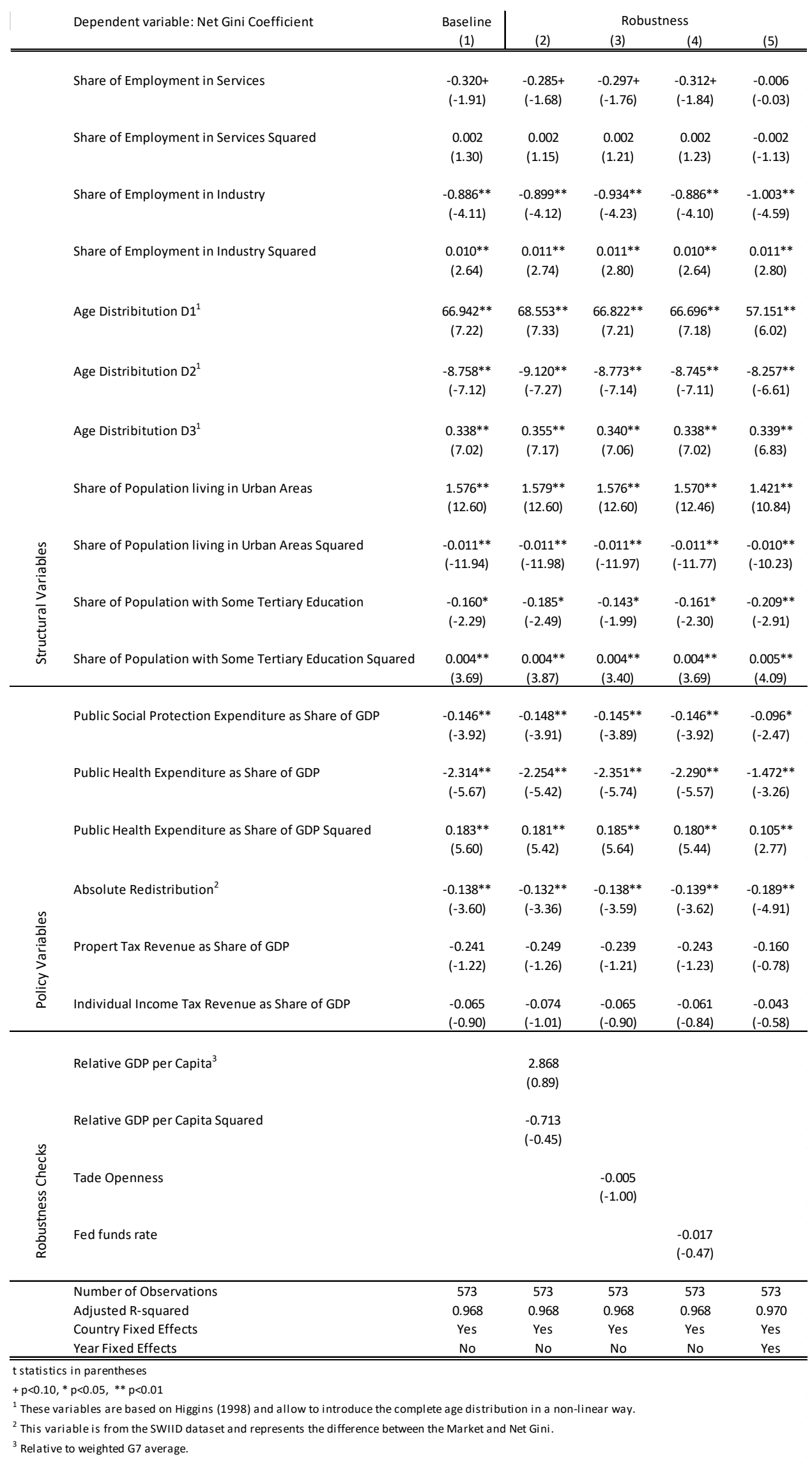

\section{CInternational Monetary Fund. Not for Redistribution}


Table: Description of Variables

\begin{tabular}{|l|l|l|}
\hline & Source & Projection Method \\
\hline $\begin{array}{l}\text { Share of Employment in Services } \\
\text { and Industry }\end{array}$ & $\begin{array}{l}\text { Groningen Growth and Development } \\
\text { Centre, World Bank }\end{array}$ & $\begin{array}{l}\text { IMF staff projections until 2030 and gradually } \\
\text { extrapolated thereafter to reach 2 percent of } \\
\text { employment in agriculture and about 25 percent in } \\
\text { industry with the remainder in services. }\end{array}$ \\
\hline Age Distribution & $\begin{array}{l}\text { UN World Population Prospects: The } \\
\text { 2017 Revision }\end{array}$ & UN World Population Prospects: The 2017 Revision \\
\hline $\begin{array}{l}\text { Share of Population living in Urban } \\
\text { Areas }\end{array}$ & $\begin{array}{l}\text { UN World Urbanization Prospects: The } \\
2014 \text { Revision }\end{array}$ & UN World Urbanization Prospects: The 2014 Revision \\
\hline $\begin{array}{l}\text { Share of Population with some } \\
\text { Tertiary Education }\end{array}$ & $\begin{array}{l}\text { Barro-Lee Educational Attainment } \\
\text { Dataset V.2.1 (Barro and Lee, 2013) }\end{array}$ & Average of G7 countries \\
\hline $\begin{array}{l}\text { Public Social Protection } \\
\text { Expenditure }\end{array}$ & SPEED & constant/Mean of top three G7 countries in 2011 \\
\hline Public Health Expenditure & CEIC, IMF EBA data & constant/Mean of top three G7 countries in 2011 \\
\hline Absolute Redistribution & SWIID Version 5.1 (Solt, 2009; Solt, & constant/Mean of top three G7 countries in 2011 \\
\hline $\begin{array}{l}\text { Property Tax Revenue as Share of } \\
\text { GDP }\end{array}$ & IMF Tax Database & constant/Mean of top three G7 countries in 2011 \\
\hline $\begin{array}{l}\text { Individual Income Tax Revenue as } \\
\text { Share of GDP }\end{array}$ & IMF Tax Database & constant/Mean of top three G7 countries in 2011 \\
\hline GDP per Capita & Penn World Table 9.0 & \\
\hline Trade Openness & IMF, WEO & \\
\hline
\end{tabular}

